dissertacoes/2006/alessandro-silva-de-oliveira.pdf>. Acesso em: 11 nov. 2016.

PAIDA, Z. Trabalhador Rural. Conteúdo Jurídico. BrasíliaDF: 2012. Disponível em: <http://www.conteudojuridico.com. $\mathrm{br} /$ ?artigos\&ver=2.36550\&seo=1>. Acesso em: 19 ago. 2017.

SCHIEFELBEIN, A. Os impactos sociais e econômicos da previdência social rural no município de Silveira Martins, RS. 2011.93 f. Dissertação (Mestrado em Geografia) - Universidade Federal de Santa Maria, 2011. Disponível em: <http://cascavel.ufsm.br/tede//tde busca/arquivo. php? $\operatorname{cod}$ Arquivo=3860> . Acesso em: 11 nov. 2016.

SCHWARZER, H. Previdência rural e combate à pobreza no Brasil Resultados de um estudo de caso no Pará. Estudos Sociedade e Agricultura, Rio de Janeiro, n. 14, p. 72-102, abr. 2000.

THEODORO, M.; DELGADO, G. C. Política Social: Universalização ou Focalização. Políticas Sociais - Acompanhamento e Análise. Brasília: IPEA, 2003.

\section{PROJETO JAÍBA - ETAPA I: ASSENTAMENTO E CONCENTRAÇÃO DA TERRA EM UM PERÍMETRO IRRIGADO}

Adâmara Santos Gonçalves Felício ${ }^{1}$ Bastiaan Philip Reydon

RESUMo: Este trabalho tem como objetivo analisar o processo de concentração da terra em perímetros irrigados do semiárido. A concentração da terra no Semiárido é de sobremaneira elevada, explicada pelo contexto histórico do processo de ocupação. Na década de 1960, a questão acerca da distribuição da terra no país e a necessidade de uma política em prol do desenvolvimento regional, fomentou debates e políticas públicas, dentre elas o desenvolvimento da agricultura irrigada, através dos perímetros públicos de irrigação, mediante a interação entre famílias assentadas e empresários agrícolas. No entanto,em muitos perímetros irrigados, tal proposta não vigorou. Destarte, o problema de pesquisa visa analisar o processo de concentração da terra em perímetros irrigados, através do estudo de caso do Projeto Jaíba Etapa I. A hipótese que norteia o estudo está baseada no argumento que permaneceram na terra, alguns poucos produtores bem-sucedidos, que encontraram oportunidade em um determinado nicho de mercado, incorrendo estes na compra de lotes daqueles que optaram em não cultivar a terra recebida. Como resultante da pesquisa realizada, compreendeu-se que falhas no processo de seleção dos assentados e endividamento, foram determinantes para a desistência de muitos assentados, criando um ambiente propício a negociação dos lotes recebidos, em um processo informal de transferência de direitos, capaz de reorientar a ocupação original do assentamento, fazendo com que o objetivo inicial não fosse cumprido, mas sim, ocorresse um processo de concentração da terra irrigada, seja através de assentados que conseguiram viabilizar o cultivo ou através de agricultores regionais que enxergaram o perímetro irrigado como uma alternativa para o desenvolvimento da fruticultura em meio ao semiárido, através do mercado de terras informal.

Graduada em Ciências Econômicas pela PUCCAMPINAS, Mestra em Desenvolvimento Econômico pelo IE/ UNICAMP e Doutoranda em Desenvolvimento Econômico pelo IE/UNICAMP. Filiação: Instituto de Economia - UNICAMP.

Professor Titular da Universidade Estadual de Campinas, professor visitante - International Center for Land Policy Studies and Training em Taiwan e professor visitante - Utrecht University. 
Palavras-chaVe: Concentração da Terra; Perímetros Irrigados; Projeto Jaíba; Mercado de Terras.

ABSTRaCT: This thesis aims to analyze the land concentration process in irrigated perimeters of the Brazilian semiarid region. Land concentration in the semi-arid region is extremely high and results from the historical context of the occupation process. In the 1960s, the question of land distribution in Brazil and the need for a regional development policy promoted debates and public policies, such as the development of irrigated agriculture by means of public irrigation perimeters and the interaction between settled families and agricultural entrepreneurs. However, this proposal failed in a great number of irrigated perimeters. The research problem of this thesis is to analyze the process of land concentration in irrigated perimeters using the case study of the Jaíba Project Stage I. The hypothesis that guides this study is based on the argument that only a few producers subsisted, i.e., those who were able to meet the demand of a certain niche market and, as a result, purchased the land lots of those who decided not to cultivate the land they had received. Research findings suggest that failures in the selection process of settlers and indebtedness were the main reasons why many settlers gave up, creating an environment that favored the sale of received land lots by means of an informal process of rights transfer, which reconfigured the original occupation of the settlement. The original goal was abandoned and a process of irrigated land concentration started to take place, backed either by settlers who were able to cultivate crops or by regional farmers who used the irrigated perimeter as an alternative for the development of fruit culture in the semiarid region by taking advantage of the informal land market.

KEYWORDS: Land concentration, Irrigated perimeters, Jaíba project, Land market.

\section{INTRODUÇão}

$\mathrm{O}$ acesso à terra em uma sociedade marcada pela concentração fundiária é tema amplamente discutido dentre os chamados legisladores e estudiosos da agropecuária e das políticas públicas no Brasil, mesmo quando entendido como uma questão de pautas de governo ou de partidos políticos. Porém, em meio a polarização que o tema é submetido na atualidade, é preciso considerar a importância do acesso à terra em ações de combate à pobreza e de segurança alimentar. Dean (1971), demonstrou que a concentração da propriedade é um dos impactos sociais e econômicos mais marcantes no Brasil.

E neste contexto, temos uma realidade adjacente as demandas pelo acesso à terra, que ainda se coloca no caso brasileiro como um campo de disputa, agricultura em larga escala x agricultura familiar. E o termo "ainda" foi utilizado com o real intuito de transportarmos ao passado recente, em que o acesso à terra ocupou os espaços de discussão dos campos da política, economia, do ativismo social e das ações em prol do desenvolvimento.

Mas, e quando posta tal análise em uma geografia social de extrema pobreza e carência até mesmo das chuvas, como é a realidade do semiárido brasileiro? Como tornar possível o acesso à terra e água? Mediante a este contexto foram formulados os programas em prol da irrigação no semiárido, em que, a pauta de desenvolvimento agrícola atendeu a políticas de expansão agrícola e de acesso à terra, fazendo com que em um perímetro irrigado, famílias da região que não tinham acesso à terra, pudessem vir a se tornarem produtores agrícolas e integrados a um mercado específico, no qual concorreriam com empresários agrícolas, detentores de parcelas de terras irrigadas dentro do mesmo perímetro.

E sob a lógica de mercado, as famílias assentadas deveriam desenvolver o cultivo agrícola. Este é o cenário preliminar conferido as famílias da Etapa I do Projeto Jaíba - objeto deste estudo de caso-, assentadas por meio de um processo de colonização, proposto para o perímetro irrigado, em que o objetivo principal era reduzir a pobreza e promover o desenvolvimento econômico mediante ao cultivo da fruticultura irrigada.

Dadas tais condições, a motivação principal da pesquisa se estabeleceu sob a perspectiva de compreender as mudanças na composição fundiária da Etapa I do Projeto Jaíba ao longo dos anos, mediante a uma hipótese de concentração da posse da terra, em meio a uma área de assentamento. Ressalvamos aqui, que não é de interesse da pesquisa tratar da questão agrária em sua totalidade, restringindo a análise de maneira específica a Etapa I do Projeto Jaíba e as relações de posse e uso da terra que se constituíram através de um processo de transferência de direitos em meio a um mercado informal de terras.

Através de pesquisa de campo, esforços foram empenhados para conceber respostas à seguinte questão: Apesar de legalmente ser impossível a venda de lotes, por que há um processo de concentração da terra em 
assentamentos rurais de perímetros irrigados? A hipótese formulada foi de a que permaneceram na terra alguns poucos produtores bem-sucedidos que encontraram oportunidades em um determinado nicho de mercado, incorrendo estes na compra de lotes vizinhos daqueles que optaram em deixar a parcela de terra recebida.

Isto posto, a proposta para este trabalho foi aprimorada através de cinco partes, consistindo inicialmente na discussão acerca da formação dos mercados de terras rurais. A segunda etapa está constituída de uma revisão bibliográfica acerca da irrigação no semiárido e da dinâmica dos perímetros irrigados. A próxima fase será de exposição do processo de implantação do Projeto Jaíba, com foco especial a Etapa I, objeto deste trabalho. O quarto momento, foi elaborado de modo que o resultado do estudo de caso proposto evidenciasse as observações propostas acerca das transformações fundiárias ocorridas no assentamento e por fim, conclusão. A proposta geral deste trabalho, foi de proporcionar respostas ao problema de pesquisa que questionou acerca do processo de saída dos assentados dos lotes recebidos e acerca da possibilidade de concentração da posse da terra através da venda de lotes do assentamento, mesmo que legalmente ser vedada tal prática.

\section{QUESTÃo AGRÁRIA E A FORMAÇão DOS MERCADOS DE TERRAS NO} BRASIL

A forma de "pensar a terra" é variável em cada local do mundo, e difere-se a maneira como outras pessoas ou comunidades pensam. Tais formas de pensar a terra vão desde a análise social até a paisagem local existente. Os conceitos de uma tribo, país ou comunidade sobre a terra, são obtidos na medida em que possam atender ao seu estilo ou as necessidades do presente, estando sempre em mudança e tornando a compreensão dos diferentes conceitos sobre a terra, um desafio para os interessados no assunto (REYDON; FELÍCIO, 2017).

Um debate recorrente na literatura do desenvolvimento da economia brasileira circunda-se pela elevada concentração da terra. Em muitos casos, diante da existência deste condicionante da estrutura social brasileira, a condição de oposição do papel da pequena produção agrícola em relação a grande propriedade, centraliza o discurso do crescimento agrícola e desenvolvimento econômico. De acordo com Reydon (2011), a elevada concentração da propriedade é reflexo do processo histórico da formação da propriedade no Brasil, com origem desde o período colonial, com a finalidade de atender interesses privados do rural brasileiro. O encadeamento da concentração fundiária na história do país, pode ser considerada como uma das principais explicações para a desigualdade social e econômica do País, fornecendo explicações a pobreza rural e a exclusão social, haja vista que os pobres não têm acesso à terra. A aquisição de terras com fins especulativos tambem é tido como um fator de elevação da concentração da propriedade, pois os "estabelecimentos passaram a demandar maiores áreas para utilização como fundo de reserva de valor" (REYDON, 2011).

Mellor (1976 apud Deininger e Byerlee, 2001) aponta que muitos autores mostraram que os ganhos de produtividade dos pequenos agricultores são capazes de promover melhores resultados de desenvolvimento em termos redução da pobreza, geração de renda e crescimento econômico, reforçando o discurso em prol da distribuição de parcela de terra a pequenos agricultores em países como o Brasil, que dispõe de uma estrutura agrária desigual, contemplada pelo modelo de modernização através da agricultura mecanizada em larga escala, em cenário de abundantes parcelas de terra (DEININGER; BYERLEE, 2001).

Ao longo do tempo, em virtude dos resultados da política fundiária brasileira, o estudo acerca da determinação e das projeções sobre os preços de terras rurais e urbanas tem se mostrado importante, no intuito de melhor compreender a realidade brasileira, sendo que segundo Plata \& Reydon (1995), a dinâmica dos mercados de terras e a evolução dos preços tem exercido um papel crucial sobre os objetivos e metas destas políticas, tornando-se um instrumento para subsidiar a tomada de decisões e reformulações, quando assim, necessário.

Segundo Plata (2002), a terra rural pode ser considerada como um recurso natural de características econômicas diferenciadas, muitas vezes complexa, mas necessária para diversas atividades econômicas; A terra além de ser um ativo real, também pode ser considerada como um ativo de reserva de valor, capaz de manter ou aumentar o valor de um período para o outro, principalmente em situações de instabilidade econômica. Dada a análise do preço de uma terra rural, quando verificado um determinado espaço geográfico, os preços ali encontrados são balizadores da situação de sua estrutura de mercado, tendo como determinantes fundamentais o seu entorno socioeconômico e político.

Plata e Reydon (1995) apontam que os preços de mercado da terra rural são utilizados pelos agentes econômicos para a tomada de decisão em 
diversos momentos de negociação acerca deste recurso natural, sendo que, os preços de mercado, são balizadores em negociações de compra e venda; referência para o governo na formulação de programas de democratização do acesso à terra, bem como para a tributação deste ativo; as instituições de crédito a utilizam para garantia do limite e segurança do crédito rural, fazendo com que de fato tais preços tornem-se parâmetro para utilização tanto no cenário econômico privado, quanto para formulação de políticas públicas.

O mercado de terras brasileiro, conforme Reydon (1992), é definido como imperfeito, uma vez que o objeto de negociação se caracteriza por uma oferta fixa, imóvel e concentrada. Neste contexto de imperfeições, a terra pode ser utilizada como fator produtivo na produção de bens agrícolas e pecuários e como um ativo de reserva de valor em um período de tempo.

A abordagem teórica a ser utilizada neste estudo tem como pano de fundo o sistema econômico capitalista. Polany (1980, pg.81) aponta que a economia de mercado é um sistema econômico dirigido, regulado e controlado por mercados, em que agentes econômicos tomam suas decisões precedidos de expectativas em auferir o maior ganho monetário possível e um mercado de terras se forma a partir da aceitação generalizada da propriedade da terra, independentemente da sua forma ou das garantias que mantem esta forma; A existência da propriedade privada da terra e suas formas jurídicas de seu estabelecimento, são fatores que quando claramente estabelecidos e garantidos, conferem liquidez ao ativo terra e a viabiliza a existência de seu mercado secundário (REYDON, 1992).

De acordo com Reydon e Felício (2017), dadas as condições e a legalidade dos negócios de um mercado de terra, este pode ser definido como: a) informal: mercados que organizam e permitem de forma simplificada os processos de transação de terra e transição de direitos, em termos comerciais são bem-sucedidos, porém, possuem suas limitações, são dotados de alta incerteza, não possuem regras claras, restando muitas vezes como irregulares ou inseguros; b) formal: são mercados de terras que envolvem instituições organizadas para a sua administração, possuem agências reguladoras (cartórios, autoridades cadastrais e outros) voltadas para realizar o gerenciamento, tributação, avaliação e planejamento, sendo que o grau de segurança é maior, suas transações comerciais são bem-sucedidas e dada a legalidade dos negócios também é composto por instituições financeiras, que participam do processo de compra, avaliação e crédito.
De todo modo, a referência geral para a formação de um mercado de terras, sempre foi a propriedade, e em regiões onde a propriedade não é formalmente estabelecida, mas é socialmente aceita, os negócios ocorrem, portanto, existe um mercado de terras, sendo justificada pelo fato de que a propriedade deve ser entendida como parte de uma convenção (REYDON, 1992).

\section{SEMIÁRIDO bRASILEIRO E A POLÍTICA NACIONAL DE IRRIGAÇÃo}

\section{O SEMIÁRIDo}

O semiárido compreende nove estados do território nacional (Bahia, Sergipe, Alagoas, Rio Grande do Norte, Paraíba, Pernambuco, Ceará, Piauí e Minas Gerais), sendo que em relação aos estados que compõem a região Nordeste, diferencia-se por incluir o Norte de Minas Gerais e excluir o estado do Maranhão, conforme Figura 01. O semiárido é responsável por $18,2 \%\left(982.566 \mathrm{~km}^{2}\right)$ do território nacional e $11 \%$ da população do país, aproximadamente 23,8 milhões de pessoas, vivem na região (IBGE, 2010).

A estrutura fundiária predominante no Semiárido confunde-se com aquela encontrada na região Nordeste; Logo, a análise realizada neste item, recorre a literatura que trata da região Nordeste, no período anterior a 2005, ano de delimitação geográfica do semiárido nordestino pelo IBGE.

O histórico do processo de desenvolvimento do Semiárido Nordestino, é marcado pela concentração de terras e atividades agrícolas como o carro chefe da economia regional, porém, destacada ênfase é conferida as irregularidades climáticas, baixo volume pluviométrico dentre mais de $60 \%$ do território que compreende a região Nordeste. Este baixo volume de chuvas, muitas vezes é agravado com as causalidades de períodos de secas prolongadas que assolam por anos a população do semiárido. Devido a este fenômeno climático, a discussão em torno do uso e posse da terra recebe menor atenção.

Apesar dos inúmeros avanços em torno da discussão da propriedade e posse da terra no cenário brasileiro e das especificidades das regiões que compõem o território nacional, pouco são aqueles que na atualidade percebem a situação de pobreza extrema do semiárido nordestino relacionada ao grave problema agrário existente na região, restando mais uma vez o uso das justificativas climáticas como a grande causa das problemáticas existentes ali. Identifica-se que em muitos casos, o Estado se faz ausente nas discussões acerca do tema, de modo que se propõe a trabalhar com os 
efeitos da seca, ao invés de aplicar olhar mais holístico sobre a sociedade nordestina, como se organiza, se define e demanda ações governamentais. Permanecem, portanto, o conservadorismo à frente do poder, representando os interesses das minorias privilegiadas e traduzindo o poder exercido através das propriedades extensas, constituídas por parcelas de terras, com solos cultiváveis de elevada fertilidade, localização geográfica e bioma propício. Em paralelo a este contexto, restam os segmentos mais frágeis da sociedade civil (CARVALHO, 1985:179).

Figura 01 - Polígono das Secas

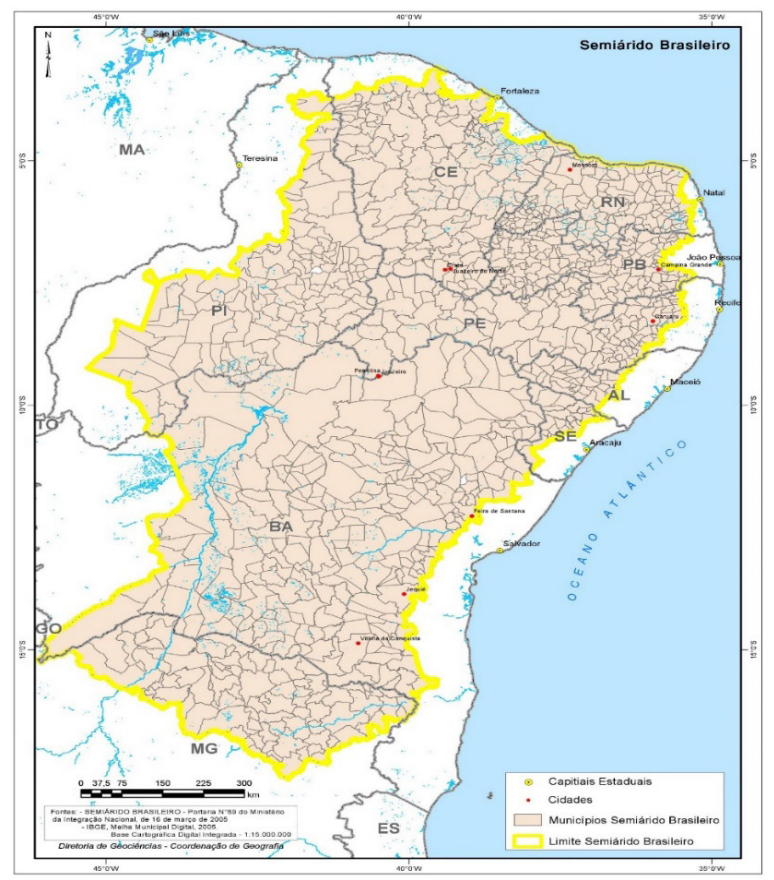

Fonte: IBGE, $2005^{3}$.

Pessoa (1990:30), aponta que ao longo de décadas e governos, muitas foram as propostas que visavam a ampliação das bases legais com a finalidade de alterar as condições estruturais do campo, todas em grande parte, realizadas por movimentos sociais e entidades representativas de diversos segmentos organizados. ${ }_{3}^{3}$ Relatório Final do Grupo de Trabalho Interministerial para Redelimitação do Semiárido Nordestino e do Polígono
das Secas, publicado em 2005.Disponível em: https://ww2.ibge.gov.br/home/geociencias/geografia/semiarido. shtm?c=4 . Acesso em: 18/07/2017.
E em detrimento de uma política de desenvolvimento regional, o governo militar a partir da década de 1960 , criou agências ${ }^{4}$ de fomento com a tentativa de reduzir as desigualdades regionais. Tais órgãos, apresentavam como objetivo principal, a execução de políticas que dinamizassem a economia de cada região do país e promovessem maior grau de integração nacional.

Ações específicas foram realizadas, de modo que a região Sul e Nordeste, receberam atenção especial. A região Sul, por sua vez, foi contemplada por conta da experiência com a prática de atividades irrigadas. A região Nordeste, que tem parcela importante do seu território, semiárido ${ }^{5}$, afetado por um problema de ordem natural, secas quase periódicas, fenômeno que na maioria das situações é tomado como um dos entraves ao desenvolvimento agrícola e pastoril, também recebeu financiamento para o desenvolvimento da agricultura irrigada (CARVALHO, 1985).

Deste modo, estaria a agricultura irrigada, dotada da capacidade de transformar a estrutura produtiva relativa à agricultura tanto do ponto de vista econômico, quanto social, pautada em uma lógica que Carvalho (1985) classificou como modernização reformista, constituída sob o regime de produção capitalista, com adoção de práticas modernas de produção, voltadas a ao aumento da produtividade em que os benefícios são compartilhados pelos diferentes atores que participam do processo produtivo, inclusive aos pequenos agricultores, através da execução de processos de reforma agrária. A modernização neste sentido, seria reformista ao propor a interação, comercialização agrícola e tomada de decisões entre os diferentes agentes ligados à produção (CARVALHO, 1985, p.466).

Porém, segundo Carvalho (1985), não seria esta a face principal do atraso econômico da agricultura do semiárido, pois o padrão da estrutura agrária ali encontrada, bem como o processo de geração e apropriação da renda da terra, também seriam fatores de entraves ao desenvolvimento econômico daquela região ${ }^{6}$. Ainda segundo o autor, em um contexto de alta concentração fundiária, o semiárido, carecia de incentivos que tratassem para além da questão agrária, constituindo-se a irrigação como um instrumento capaz de

${ }^{4}$ SUDENE criada em 1959, SUDAM criada em 1966 e SUDECO criada em 1967.

O semiárido compreende nove estados do território nacional (Bahia, Sergipe, Alagoas, Rio Grande do Norte, Paraíba, Pernambuco, Ceará, Piauí e Minas Gerais).

${ }^{6}$ Como dantes já visto neste trabalho, a concentração fundiária é parte do contexto histórico da ocupação territorial desta região do país, de modo que é derivada do capital e poder político das classes conservadoras, que por sua vez detém parcelas importantes de terras produtivas, porém, em sua maioria ociosas, em contradição ao grande número de trabalhadores, em especial aqueles que ocupam o semiárido, que lutam pelo acesso à terra e ao mercado de trabalho. 
tornar como potenciais áreas de solo árido, conferindo-lhes dinamicidade econômica e social e de uso do solo e água.

\section{Marco Legal e Institucional da Política Nacional de IrrigaÇão} COMO PROPOSTA DE DESENVOLVIMENTO AO SEMIÁRIDO

O Governo Federal instituiu em 1968, no bojo da elaboração dos Planos Nacionais de Desenvolvimento-PND, o Grupo Executivo de Irrigação e Desenvolvimento Agrário - GEIDA, com o objetivo de constituir uma política de irrigação para o Brasil, ação realizada através do Programa Plurianual de Irrigação-PPI, lançado em 1970, que estabelecia as diretrizes para a política de irrigação no país, com grande parcela dos investimentos voltados a região Nordeste. A intenção principal do PPI, era que a irrigação tornasse um instrumento de promoção do crescimento econômico, com responsabilidade de implementação dirigida a DNOCS e SUVALE (BRASIL,2008, pg.09). Segundo Brito (1991), o PPI foi responsável pela reorientação do Estado brasileiro em relação à agricultura irrigada, pois estabeleceu metas a serem cumpridas e a ampliação do conhecimento acerca dos recursos disponíveis, baseados em relatórios técnicos e estudos de viabilidade econômica.

O Programa de Integração Nacional - PIN, criado através do DecretoLei $\mathrm{n}^{\circ} 1.106 / 1970$, foi o responsável pelo financiamento da primeira fase do Plano Nacional de Irrigação, que teve como pano de fundo, I PND lançado em 1972 e o II PND em 1979. Em outubro de 1974, foi criado o Programa de Desenvolvimento de Áreas Integradas do Nordeste, denominado como POLONORDESTE, com a finalidade de promover o desenvolvimento e a modernização das atividades agropecuárias de áreas prioritárias do Nordeste (essencialmente aquelas afetadas pelas secas), conforme texto do Decreto $\mathrm{n}^{\circ} 79.794$ de outubro de 1974.

Neste período de desenvolvimento de planos e programas de incentivo e desenvolvimento da agricultura irrigada, percebe-se que o governo da ocasião, atuou sob uma perspectiva intervencionista mediante a ampliação do conhecimento acerca dos recursos naturais disponíveis e pela implementação de políticas a nível nacional. Foram estabelecidas diretrizes e metas através do I Plano Nacional de Irrigação, todas capitaneadas pelo setor público, mas claramente voltadas ao estímulo da iniciativa privada. Este encabeçamento das ações pelo setor público, ganhou um sentido diferenciado, apenas quando do Programa Nacional para Aproveitamento Racional de Várzeas Irrigáveis
(PROVARZEAS), do Programa de Financiamento de Equipamentos de Irrigação (PROFIR) e da criação de "lotes empresariais" nos projetos públicos de irrigação, que conferiu a condição de manifestação da iniciativa privada (BRASIL, 2008, pg. 11).

E mediante ao estabelecimento de tais condições, o modelo da grande irrigação pública, foi aquele empreendido em maior escala pela Política Nacional de Irrigação na região do semiárido Nordestino, pois conforme prevê o Projeto de Irrigação Nacional, este modelo de infraestrutura irrigada permite maior integração social e desenvolvimento socioeconômico, pois em sua estrutura originária prevê a implantação de rebuscada engenharia, com a finalidade de captar, armazenar e distribuir águas a áreas afetadas pela indisponibilidade hídrica, conformando em seu projeto original irrigantes/ colonos, pequenos e médios empresários e os empresários agroindustriais.

A exploração de um grande projeto de irrigação, conforme marco regulatório, prevê a interação de colonos e empresários como um modo de desenvolver e expandir a agricultura irrigada no semiárido. A terra é caracterizada como um meio de produção para ambos, com o diferencial que para o caso dos colonos, este meio de produção privado foi transformado em um patrimônio público através do processo de desapropriação, medida que torna o colono dependente das decisões do ente governamental que administra o perímetro e determina o tipo de exploração que o lote deverá receber. Tal planejamento produtivo é realizado com base em pesquisas de mercado e prevê o atendimento das necessidades "do mercado" (CODEVASF, 1984).

Projeto Jaíba: concepção inicial e aspectos formais da IMPLANTAÇÃo

Pautado em uma política nacional para o desenvolvimento agrícola, combate as secas e expansão da fronteira agrícola, o Projeto Jaíba foi considerado como um projeto público de irrigação de grande potencial transformador para a região Norte do estado de Minas Gerais, periodicamente castigada pela seca, pobreza extrema, economia incipiente e isolamento territorial. Previa-se a modernização da agricultura local, integração econômica e aumento da renda dos trabalhadores, a partir de uma produção agrícola moderna pautada na fruticultura em áreas irrigadas a partir do rio São Francisco e suas vertentes.

Concebido em decorrência do sucesso de um projeto piloto de irrigação 
em terras devolutas na Mata do Jaíba, o Projeto Jaíba assumiu projeção nacional baseado em um conjunto de aportes financeiros voltados para o desenvolvimento agrícola, que teve a execução da infraestrutura iniciada em 1979, com o intuito de construir-se o maior perímetro irrigado da América Latina capaz de contribuir para o abastecimento do Sudeste brasileiro. Assim sendo, a etapa de conformação do empreendimento que viria a ser o Projeto Jaíba coincidiu com o período em que o desenvolvimento da agricultura irrigada crescia em todo o Brasil, e mediante a este cenário de criação de programas de fomento para o desenvolvimento da região nordeste, no ano de 1979, através do Convênio n59/79, firmado entre o Ministério do Interior e Estado de Minas Gerais, determinou que as ações de desenvolvimento, estudos, projetos e obras de engenharia do então denominado Distrito Agroindustrial Jaíba e Projeto de Irrigação do Mocambinho, seriam de responsabilidade da Companhia de Desenvolvimento dos Vales do São Francisco e Alto Parnaíba-CODEVASF, com apoio e assistência técnica da Ruralminas. Por meio deste instrumento, ficou estabelecido que dos 230.000 hectares, lotados para compor o perímetro irrigado, 100.000 hectares seriam destinados para execução das obras de infraestrutura coletiva de irrigação e loteamentos destinados a pequenos produtores e empresários. Esta área, somada a mais 130.000 ha de terras devolutas, tornaria um projeto de grande irrigação pública, conforme os moldes previstos no Plano Nacional de Irrigação.

O perímetro irrigável do Jaíba, foi planejado para se constituir como um polo de desenvolvimento regional a partir da agricultura irrigada, pautada em estancia superior pela prática da fruticultura, cultura selecionada com base na adaptação do solo e ás condições climáticas do vale do São Francisco, estando as fruteiras tropicais como: abacate, acerola, banana, goiaba, mamão e manga como perfeitas para o cultivo na região (PLANVASF, 1989, pg.128).

O Projeto Jaíba, foi dividido em quatro etapas de implantação (Etapa I, II, III e IV), sendo que dos 100.000 ha considerados como aptos a irrigação, optou-se por irrigar aproximadamente 66.0000 ha e destinar os 34.000 ha restantes em áreas de proteção ambiental, reserva legal, infraestrutura de canais e bombeamento de água e administração do perímetro irrigável.
Figura 02 - Localização da Área de Estudo - Projeto de Irrigação Jaíba, Jaíba/MG

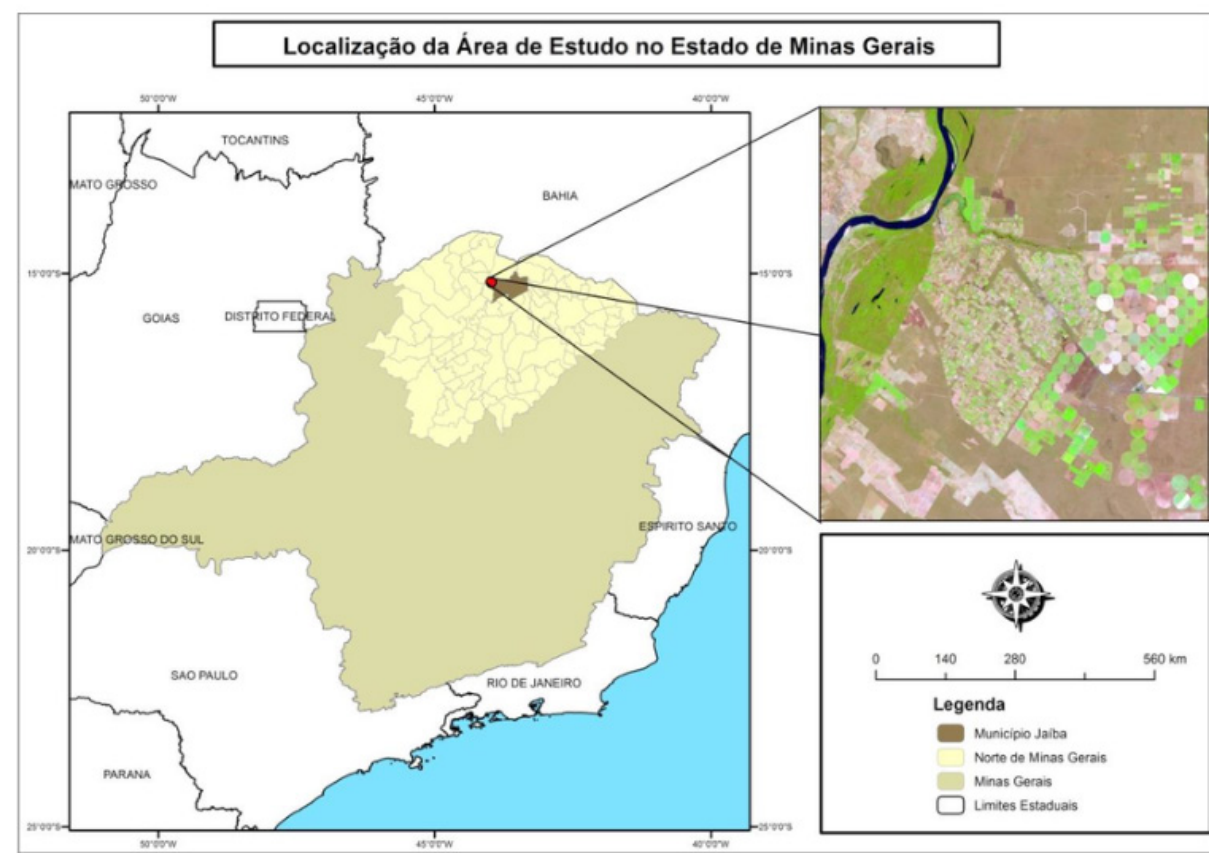

Fonte: Veloso et al, 2015.

\section{Início da Implantação do Projeto JaÍba}

A implantação do Projeto Jaíba é considerada foi considerada como extremamente morosa devido as descontinuidades de recursos e crise econômica que o país passou ao fim dos anos 1970. Calcula-se que no início do projeto, mais de US\$189,9 milhões ${ }^{7}$ tenham sido gastos apenas com a infraestrutura de bombeamento das águas do São Francisco até o nivelamento dos canais (CODEVASF, mimeo).

No início da década de 1980, alguns poucos irrigantes foram assentados na gleba $\mathrm{D}$, pertencente ao projeto piloto de irrigação, denominado como Mocambinho. Neste período era grande a especulação em torno das conclusões das obras, tendo em que vista o Projeto Jaíba havia sido planejado para se tornar um agente de desenvolvimento socioeconômico na região Norte de Minas Gerais. Porém, praticamente 10 anos depois, o que se via era porções de obras inacabadas e um enorme contingente populacional à espera do início da operação do Projeto Jaíba (RODRIGUES et al., 2000). ${ }^{7}$ A valores do período. 
Figura 03 - Layout Geral do Projeto Jaíba

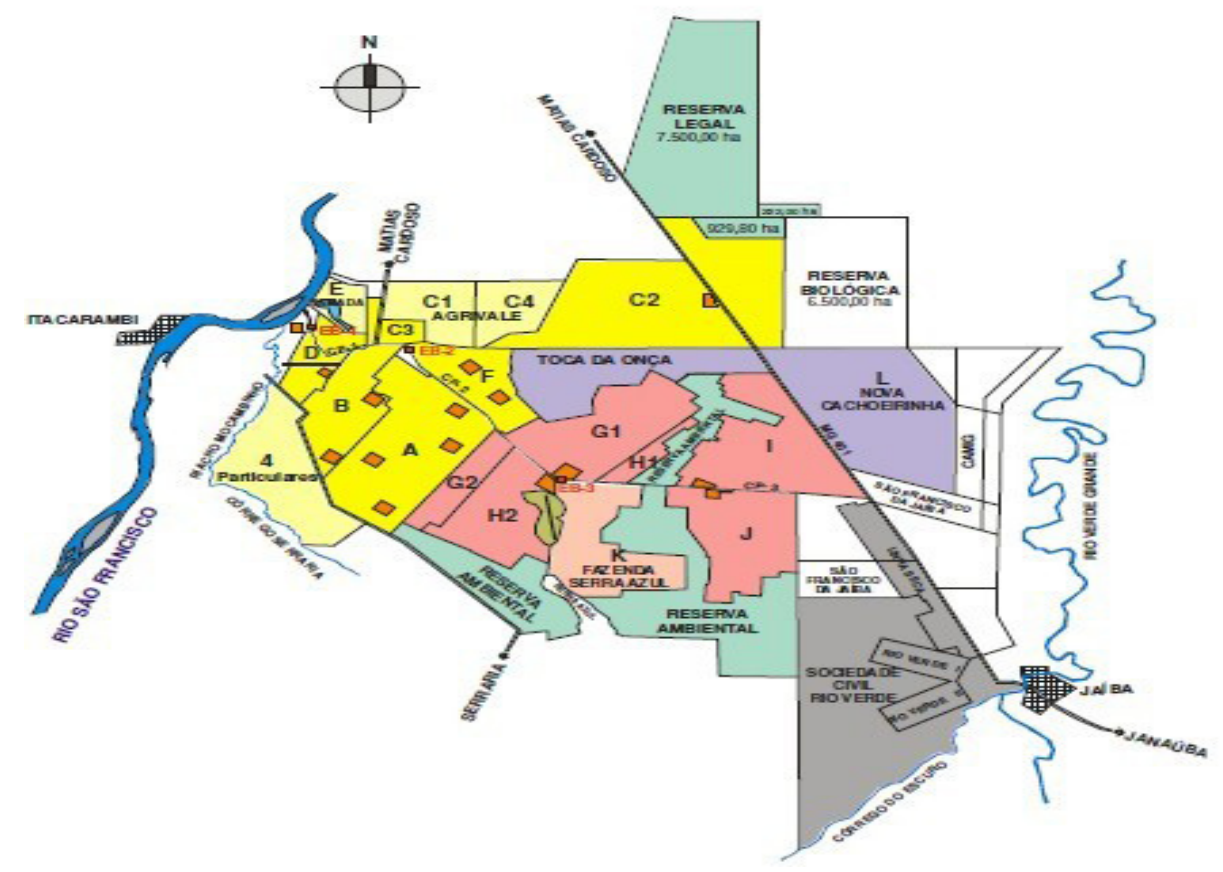

Fonte: Distrito de Irrigação de Jaíba-DIJ, 2016.

Figura 04 - Distribuição das Etapas que compõem o Projeto Jaíba.

\begin{tabular}{|c|c|c|}
\hline \multicolumn{3}{|c|}{ ETAPA I } \\
\hline \multicolumn{3}{|c|}{ Área Brta Total $\ldots$} \\
\hline Glebas & Area Bruta (ha) & Área Irrigivel (ha \\
\hline $\mathrm{A}, \mathrm{B}, \mathrm{C} 2, \mathrm{C} 3, \mathrm{D}, \mathrm{F}$ & $23.919,33$ & $17.389,58$ \\
\hline $\begin{array}{l}\text { E (Particular) } \\
C_{1} \text { e C4 (Paricular) }\end{array}$ & & \\
\hline 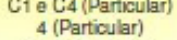 & $\begin{array}{l}3.832,10 \\
4.546 .40\end{array}$ & $\begin{array}{l}3.200000 \\
3.800,00\end{array}$ \\
\hline Reserva Legal & $8.651,80$ & \\
\hline Total & $41.611,13$ & $24.669,68$ \\
\hline
\end{tabular}

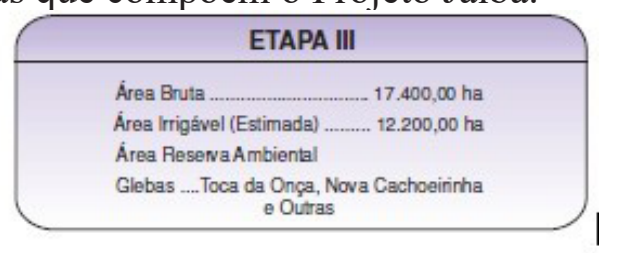

\begin{tabular}{|c|c|c|}
\hline \multicolumn{3}{|c|}{ ETAPA II } \\
\hline Área Bruta Total & & $34.772,76 \mathrm{ha}$ \\
\hline Glebas & Área Brrta (ha) & Area Irrigável (ha) \\
\hline $\begin{array}{c}\mathrm{G}, \mathrm{H}, \mathrm{I}, \mathrm{J} \\
\text { K(Serra, Azul) }\end{array}$ & $\begin{array}{r}18.350,69 \\
4255.57\end{array}$ & $\begin{array}{c}16.276,40 \\
3.000,00\end{array}$ \\
\hline Morro Solto & $\begin{array}{r}249,34 \\
1.239\end{array}$ & \\
\hline $\begin{array}{l}\text { Resenva Ambiential } \\
\text { Outras Áreas }\end{array}$ & $\begin{array}{r}11.325,31 \\
591,85\end{array}$ & \\
\hline Total & $34.772,76$ & $19.276,40$ \\
\hline
\end{tabular}

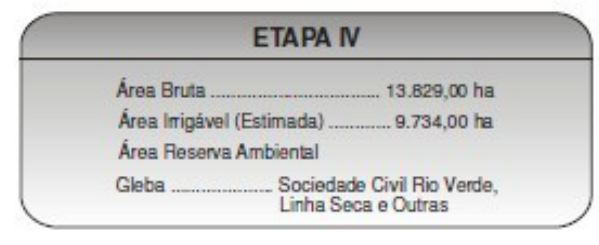

Fonte: Distrito de Irrigação de Jaíba-DIJ, 2016.
De acordo com a CODEVASF (mimeo), ao fim das primeiras obras de infraestrutura, bombeamento e construção dos principais canais de irrigação, o orçamento acabou e foi preciso buscar novos recursos financeiros para dar continuidade às obras e ações do perímetro irrigável.

A etapa I foi originalmente implantada com os recursos do Banco Mundial ${ }^{8}$, de modo que, a condição de acesso à terra como um instrumento de redução da pobreza, foi privilegiado no momento de seleção dos colonos. A meta principal da realização da área de colonização dentro do Projeto Jaíba, era proporcionar aos produtores condições administrativas, técnicas e econômicas para contribuir com o desenvolvimento da agricultura irrigada e agronegócio na região Norte de Minas, promovendo a fixação do homem ao campo e sua inclusão no processo produtivo (CODEVASF, mimeo).

A etapa II, foi projetada para receber empreendimentos empresariais. Dotada de uma área de 34.772,76 ha, das quais 19.276,40 ha são irrigáveis. Esta etapa do Projeto Jaíba foi planejada com o objetivo de diversificar e aprimorar a estrutura socioeconômica do perímetro irrigável. Destinada a pequenos e médios empresários agrícolas, a forma de acesso é via concorrência pública, coordenado pelo governo do estado de Minas Gerais.

As etapas III e IV, de acordo com o Distrito de Irrigação Jaíba ainda não receberam a infraestrutura específica para a irrigação, sendo contempladas apenas pelos canais principais de irrigação, e as áreas destas etapas são de 12.000 ha e 9.734 ha respectivamente, somando 21.934 de hectares disponíveis para irrigação, assentamento e produção agrícola.

Portanto, a única etapa concluída do empreendimento de irrigação, Projeto Jaíba, foi a Etapa I, e por este motivo, tornou-se objeto de análise desta pesquisa, haja visto que as demais etapas não são passíveis de análise exploratória, dadas as condições parciais de operação.

\section{ESTUdO DE CASO: PROJETO JAÍBA - ETAPA I - ACESSO À TERRA EM MEIO A UM CONTEXTO DE DESENVOLVIMENTO AGRÍCOLA} ${ }^{8}$ No iní́cio de 1986 o Banco Mundial passou a apoiar financeiramente o Projeto Jaíba, mediante a concessão de
empréstimo ao Governo Federal, através da CODEVASF. O valor alcançado através deste empréstimo, tinha como
objetivo principal concluir as obras referente a Etapa I por meio da irrigação de 24.669 há (WORLD BANK,
1988). A proposta do Banco Mundial como condições fins para a concessão do empréstimo, US\$71 milhões foram
destinados a conclusão da Etapa I do Projeto Jaíba, sob a condição principal de famílias agricultoras, que não
detinham de parcela de terra, fossem inseridos no processo de produção do projeto (WORLD BANK, 1988).A
partir deste aporte financeiro foram construídos canais de irrigação que seriam responsáveis por irrigar os lotes
ocupados pelas famílias colonas assentadas, infraestrutura de irrigação, eletrificação e estradas de acesso, como
será apresentado a seguir (CODEVASF, mimeo). 
Estaria ocorrendo um processo de concentração da posse da terra na Etapa I do Projeto Jaíba?

Esta foi a percepção inicial da pesquisa, resultante de uma conversa guiada com agricultores da região. Com uma pesquisa motivada em compreender os movimentos de transformação da estrutura fundiária que ali ocorriam, histórias de quem permaneceu, de quem comprou, de quem saiu, foram os instrumentos valorosos para a descrição dos resultados. Um fato já era conhecido por todos os entrevistados: muitos assentados do Projeto Jaíba, não permaneceram em suas terras e ocorre no mesmo a negociação informal de lotes, situados na área destinada ao assentamento.

Por meio de visita realizada em setembro de 2017, junto a CODEVASF (sede de Montes Claros) e Distrito de Irrigação Jaíba (sede em Mocambinho), foram realizadas entrevistas com os diretores responsáveis pelos dois órgãos com o objetivo de alcançar informações acerca das mudanças na estrutura fundiária do Projeto Jaíba ao longo dos mais de 30 anos de implantação. Através das entrevistas e informações disponibilizadas pelos representantes, foi possível identificar que de fato, ocorrera um reordenamento da composição fundiária da Etapa I do Projeto Jaíba, justificado pela negociação informal das parcelas de terras recebidas pelos assentados, que resultara na modificação da distribuição da posse dentre os ocupantes daquela área, com situações de posse de lotes em quantidades superior a aqueles definidas legalmente para implantação e gestão do perímetro irrigado.

Porém, segundo os próprios representantes dos órgãos responsáveis pela gestão do perímetro, este processo não foi captado através de levantamento fundiário consolidado, mas sim, através de informações emitidas a cunho não oficial dos técnicos que realizam visitas in loco aos assentados. Questionados acerca da existência de uma rotina de fiscalização e acompanhamento dos assentados, os representantes foram categóricos em afirmar que tais procedimentos não são realizados, restando apenas o acompanhamento dos técnicos da Empresa de Assistência Técnica e Extensão Rural do Estado de Minas Gerais - EMATER-MG, que tem o objetivo específico de acompanhar e fortalecer o plantio e comercialização empreendida pelos assentados.

Ainda, acerca das mudanças que ocorreram na distribuição da posse dos lotes destinados aos assentados do Projeto Jaíba, foi questionado qual seria o retrato atual do assentamento, e na mesma frequência, as afirmações provenientes da CODEVASF, quanto do DIJ, indicaram que é real a negociação de lotes entre os assentados, bem como, entre assentados e indivíduos externos ao perímetro de irrigação, de modo que aproximadamente de $30 \%$ dos lotes ainda estariam em posse dos assentados originários.

O estudo apresentado por Couto (2016), através de uma amostra composta por 165 lotes da gleba F da Etapa I do Jaíba revelou que 35,15\% eram proprietários com titularidade (CCU ou Matrícula), 33,33\% deste grupo eram fruto de processos de aquisição via contrato de compra e venda, $14,55 \%$ eram lotes explorados por arrendatários e 16,97\% dos lotes eram explorados por familiares. Logo, a afirmação apresentada pela CODEVASF foi corroborada através do estudo.

No entanto, o desejo deste estudo era avançar sobre a questão do domínio dos lotes e apresentar maiores afirmações acerca de como estava distribuída a posse dos lotes no assentamento implantado na Etapa I.

Indícios decorrentes das afirmações feitas pelos técnicos entrevistados e através da percepção da pesquisadora ao realizar a visita ao assentamento em outubro/2017, indicavam a alteração da composição fundiária do assentamento, porém, a pesquisa bibliográfica sobre o Projeto Jaíba foi realizada e não foram encontradas fontes de dados oficiais que demonstrassem tais mudanças, nem ao menos dissertações ou teses que tratassem de maneira profunda deste tema. Logo era preciso demonstrar e entender os porquês destas modificações, bem como, de que forma elas estavam ocorrendo.

E assim ficou claro que apenas uma pesquisa de campo, realizada a partir de entrevistas diferentes atores sociais envolvidos ao perímetro irrigado, bem como, aqueles considerados como os protagonistas deste processo: agricultores da Etapa I, seria fundamental para conferir respostas ao questionamento realizado, bem como, para comprovação ou negação da hipótese sugerida.

\section{Metodologia PaRa o estudo}

A metodologia utilizada para esta etapa da pesquisa, foi a combinação do levantamento bibliográfico acerca da Etapa I do Projeto Jaíba junto aos órgãos responsáveis por sua concepção, implantação e execução atual e pesquisa de campo. Esta fase de pesquisa compreendeu-se entre os meses de outubro a dezembro de 2017.

Os critérios estabelecidos para a realização da pesquisa de campo foram estipulados em etapas. A primeira, foi composta pela coleta de dados 
secundários acerca do processo de seleção para o assentamento e estrutura fundiária da Etapa I do Projeto de Irrigação Jaíba. Através da visita a CODEVASF $-1^{\mathrm{a}}$ Superintendência em Montes Claros-MG e DIJ na cidade de Jaíba, foram realizadas entrevistas com funcionários responsáveis pela coordenação fundiária, gestão de dados e serviços, sendo que relatórios, cópias de convênios e contratos, foram disponibilizados por estes órgãos ${ }^{9}$.

A segunda etapa compreendeu o estudo de campo nas glebas que compõem a Etapa I do perímetro irrigado. Entrevistas foram realizadas mediante a formulação prévia de questionário semiestruturado com questões direcionadas a caracterização do irrigante selecionado. Nesta etapa de pesquisa, já era de conhecimento da pesquisadora a existência da prática de negociação de lotes na Etapa I, logo, o questionário foi formulado de modo a identificar o irrigante selecionado mediante a condição de formalidade dos lotes.

Como estratégia para alcançar uma amostra diversificada de entrevistas junto aos assentados que compõem o perímetro irrigado, por meio de um veículo, os canais principais de irrigação do perímetro, foram percorridos. Considerando, que a área destinada ao assentamento é dividida em glebas, o objetivo era obter uma amostra de aproximadamente $5 \%$ de cada gleba, para que as informações pudessem ser estatisticamente confiáveis. O propósito era captar um número de entrevistas representativas para cada fase de assentamento da Etapa I, combinadas entre irrigantes assentados e compradores de cada gleba. Assim sendo, a unidade selecionada para identificação dos questionários foi unidade de negócio, ou seja, lote adquirido, resultando em um total de 120 questionários aplicados.

Uma série de entrevistas foram realizadas para compor a pesquisa de opinião junto a atores-chaves da região do perímetro irrigado. Definiu-se um representante entrevistado para cada instituição. $\mathrm{O}$ critério de escolha das instituições baseou-se nas interligações que as mesmas dispunham para com a Etapa I do Projeto Jaíba. Privilegiou-se para a escolha do entrevistado a condição de representatividade dentro da instituição, tempo de atuação e área de atuação (correlata ao objeto da pesquisa). Portanto, foram selecionadas seis instituições: Sindicato de Trabalhadores Rurais, Instituto Mineiro de Agropecuária-IMA, DIJ, Prefeitura M. de Jaíba, Associação dos Agricultores da Gleba A (gleba com maior número de assentados) e EMATER.

${ }^{9}$ Apesar do assentamento das famílias na Etapa I do Projeto Jaíba ter sido realizado pela Ruralminas, esta autarquia do governo de Minas Gerais teve suas atividades encerradas, restando no momento atual apenas a CODEVASF sob a coordenação da Etapa I, até que o governo de Minas Gerais, designe uma nova gerência ao Projeto Jaíba.
Estrutura Fundiária do Projeto Jaíba-Etapa I

A etapa I do Projeto Jaíba, considerada a área bruta, ocupa uma superfície total de 32.959,33 hectares, sendo demarcada em dez glebas dispostas ao longo dos canais de irrigação. Seis destas glebas, A, B, C3, C2, D e F eram consideradas devolutas, portanto, pertenciam ao Estado e foram destinadas as famílias assentadas em processo de colonização. A gleba C2 é uma área pertencente aos municípios de Jaíba e Matias Cardoso, e foi destinada a pequenos e médios empresários. A gleba 4, é composta por propriedades particulares, pré-existentes ao projeto de irrigação, e foram beneficiadas através do transporte de águas dos canais que abastecem as glebas Ae B. As glebas $\mathrm{C} 1, \mathrm{C} 4$ e E são glebas pertencentes a empresas privadas. A gleba D, é ocupada pelo perímetro de Mocambinho, projeto piloto do Projeto Jaíba (CODEVASF, mimeo). Vide QUADRO 1:

Quadro 01 - Ocupação do Perímetro Irrigável - Etapa I.

\begin{tabular}{|c|c|c|c|}
\hline \multicolumn{4}{|c|}{ Quadro de ocupação Perímetro Irrigável Etapa I } \\
\hline \multirow{2}{*}{ GLEBA } & \multicolumn{2}{|c|}{ ÁREAS (ha) } & \multirow{2}{*}{$\begin{array}{c}\text { N. }{ }^{\circ} \text { DE LO- } \\
\text { TES }\end{array}$} \\
\hline & BRUTA & IRRIGÁVEL & \\
\hline A & $6.038,21$ & $4.296,79$ & 845 \\
\hline B & $2.829,26$ & $2.055,85$ & 399 \\
\hline C3 & 488,63 & 295,02 & 57 \\
\hline $\mathbf{D}$ & $2.669,87$ & $1.038,79$ & 201 \\
\hline $\mathbf{F}$ & $2.336,16$ & $1.660,23$ & 326 \\
\hline Subtotal & $14.362,13$ & $9.346,68$ & 1.828 \\
\hline $\begin{array}{c}\text { C2 (Pequenos e Médios Empre- } \\
\text { sários) }\end{array}$ & $9.557,20$ & $8.042,90$ & 325 \\
\hline Subtotal & \multirow[t]{2}{*}{$9.557,20$} & \multirow[t]{2}{*}{$8.042,90$} & \multirow[t]{2}{*}{325} \\
\hline $\begin{array}{c}\text { Área de Particulares } \\
\text { beneficiados pela infraestrutura } \\
\text { instalada na Etapa I }\end{array}$ & & & \\
\hline C1 e C4 (particular) & $3.832,10$ & $3.200,00$ & - \\
\hline E ( Brasnica ${ }^{1}$ ) & 661,5 & 280 & - \\
\hline 4 (particular) & $4.546,40$ & $3.800,00$ & - \\
\hline Subtotal & $9.040,00$ & $7.280,00$ & - \\
\hline Total Etapa I & $32.959,33$ & $24.669,58$ & 2.153 \\
\hline
\end{tabular}

Fonte: adaptado, Distrito de Irrigação de Jaíba-DIJ, 2016. 
Quando observado o quadro acima, percebe-se que o projeto original para a Etapa I do Projeto Jaíba, já previa em uma única área, através da separação por lotes, a interação entre famílias assentadas e empresas, de modo que sob o contexto de uma estrutura fundiária moderna, baseada em sistemas de irrigação, passariam a conviver dois modos de produção diferentes, o primeiro baseado na produção familiar, portador de situações específicas e particulares, que ao mesmo tempo em que é "proprietário dos meios de produção" também é responsável pelo trabalho utilizado na produção e que produz em grande parte para o consumo próprio (WANDERLEY,2000), e o segundo modo de produção, aquele dotado de capital, que utiliza mão de obra remunerada, produz para o mercado e detêm do conhecimento prévio necessário a ampliação da produtividade.

A Etapa 1 do Projeto Jaíba detinha em sua estrutura fundiária ocupada, $38 \%$ da área irrigável destinada as famílias agricultoras/pequenos produtores, $33 \%$ da área irrigável ocupada pelos Pequenos e Médios Empresários, sendo o empreendimento agrícola Brasnica e as áreas particulares responsáveis por $29 \%$ da área irrigável. Dentre a parcela destinada ao assentamento dos colonos, se fazem presentes os núcleos de apoio (com escritórios da CODEVASF, DIJ, EMATER, escolas e posto de saúde), estação de bombeamento e infraestrutura elétrica, vide FIGURA 01:

Figura 05 - Ficha Fundiária - Projeto Jaíba Etapa I.

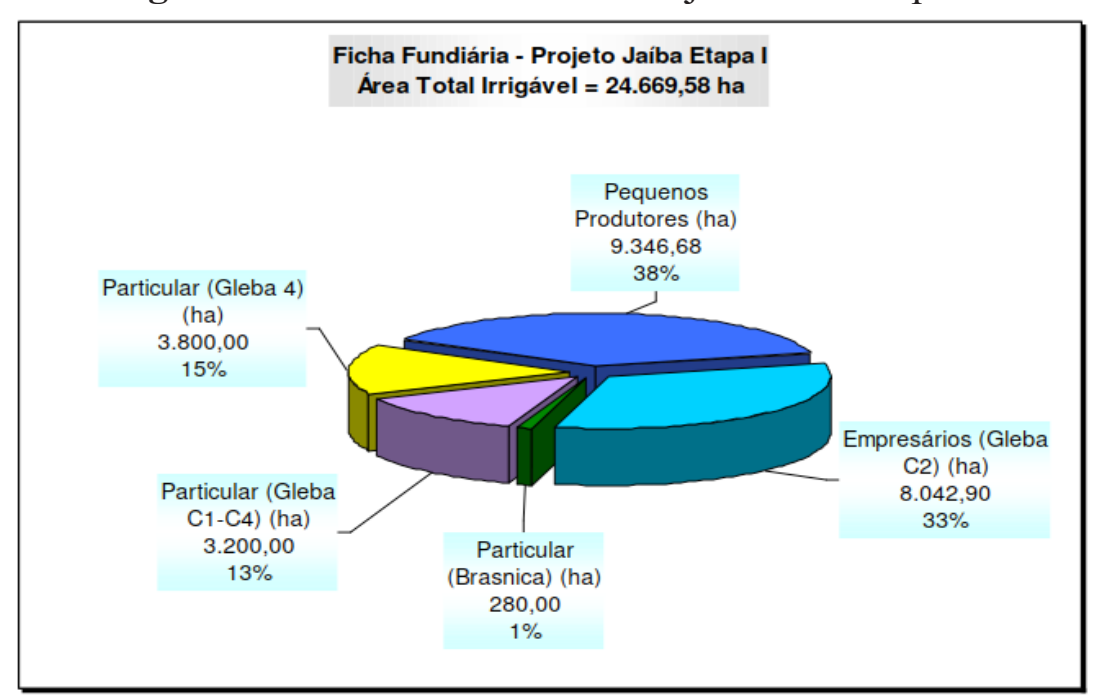

Fonte: DIJ, 2016.
Através da Figura 05, é possível compreender que desde a concepção formal da Etapa I, já estava presente a assimetria da posse da terra dentre aqueles que tornariam seus proprietários, pois a soma da área irrigável destinada aos chamados particulares representa $62 \%(15.322,90$ ha) da área total irrigável que compõe a Etapa I, enquanto a área irrigável destinada aos pequenos produtores, ou ainda, aos assentados, é de 38\% (9.346,68 ha).

O quadro 02 , logo abaixo, espelha a realidade fundiária da Etapa I e valida a máxima nacional de que "muitos têm pouco e poucos tem muito" quanto à distribuição da terra, bem como, reitera os argumentos apresentados até o momento, de que estaria concentrada a posse da terra no perímetro irrigado.

Quadro 02 - Quadro de Distribuição dos Lotes - Etapa I

\begin{tabular}{|l|c|c|}
\hline \multicolumn{2}{|c|}{ Quadro de Distribuição dos Lotes - Perímetro Irrigável Etapa I } \\
\hline Tipo de Produtores & $\begin{array}{c}\text { Área } \\
\text { Irrigável(ha) }\end{array}$ & $\begin{array}{c}\mathbf{N}^{\mathbf{0}} \text { de } \\
\text { Lotes }\end{array}$ \\
\hline Pequenos Produtores & $9.346,68$ & 1828 \\
\hline Médios Empresários/Produtores & $8.042,90$ ha & 325 \\
\hline Grandes Empresários/Produtores & 7280,00 há & 3 \\
\hline
\end{tabular}

Fonte: adaptado, DIJ, 2016.

Logo, desde a fase inicial de operacionalização da Etapa I, o padrão de elevada concentração fundiária foi reiterado no interior do perímetro irrigado Projeto Jaíba.

Apresentada a análise geral acerca da distribuição da posse da terra na Etapa I do Projeto Jaíba, o próximo passo será realizar o estudo da situação fundiária da área destinada aos colonos assentados na Etapa I, constituindo o objeto principal desta pesquisa a partir dos levantamentos e entrevistas efetuadas durante a pesquisa de campo.

\section{Processo de Seleção dos Assentados na Etapa I}

O processo de seleção dos assentados da Etapa I do Projeto Jaíba foi capitaneada pela RURALMINAS, responsável pela gestão da estrutura fundiária do perímetro irrigado (CODEVASF, mimeo). Vagas informações foram encontradas acerca do assentamento das primeiras glebas por meio da pesquisa documental, de modo que a CODEVASF, limita-se a disponibilizar a informação de que participou de forma indireta da seleção.

De todo modo, por se tratar de terras devolutas, que tiveram sua 
administração repassada a extinta RURALMINAS, é importante destacar que o processo realizado para o assentamento das famílias agricultoras, foi o da colonização, definida através do Decreto Federal nº59.428/66 como:

"Colonização é toda atividade oficial ou particular destinada a dar acesso à propriedade da terra e a promover seu aproveitamento econômico, mediante o exercício de atividades agrícolas, pecuárias e agroindustriais, através da divisão em lotes ou parcelas, dimensionados de acordo com as regiões definidas na regulamentação do Estatuto da Terra, ou através das cooperativas de produção nela previstas" (BRASIL, Decreto n59.428, 01 de novembro de 1966 , art. $5^{\circ}$ ).

Logo, a colonização também tem como objeto de mudança, a promoção da melhor distribuição da terra, modificando o regime de posse e uso, visando o atendimento de princípios que perpassam pela justiça social, desenvolvimento rural e aumento da produção. E na Etapa I do Projeto Jaíba, esta "forma" de assentamento, previa a exploração do lote ou parcela de terra para o sustento, através da mão de obra familiar, estando a propriedade da terra recebida vinculada a RURALMINAS. Portanto, os lotes foram disponibilizados aos colonos mediante a emissão da Concessão de Direito Real de Uso - CDRU, documento comprobatório do recebimento do lote por parte da CODEVASF e Ruralminas, que veda até o recebimento da escritura do lote, a venda, aluguel, doação, arrendamento ou empréstimos do lote recebido a terceiros (RODRIGUES, 1998).

Mediante a seleção realizada dentre os pequenos agricultores da região norte de Minas Gerais, cada irrigante escolhido recebeu um lote de aproximadamente ${ }^{10} 5$ hectares, dotado da infraestrutura necessária para irrigação, sendo que dada a disponibilidade a pagar de cada selecionado, o mesmo poderia acessar até a 04 lotes familiares -20 hectares, com a função de realizar o cultivo suficiente para o sustento da família e excedentes para manutenção da estrutura de irrigação e captação de água. Como forma de subsidiar e apoiar o período de adaptação dos assentados, no primeiro ano o custeio referente a irrigação não foi cobrado. Após este período, a tarifação da água passou a ser cobrada, com base no tamanho da área recebida e

${ }^{10} \mathrm{O}$ recorrente uso do termo "aproximadamente" quando se tratar das medidas das áreas e lotes do Projeto Jaíba deve-se pelo fato do tamanho dos lotes variar de um para outro, dada a espacialidade das glebas construídas em torno dos canais. As medidas dos lotes são de $140 \mathrm{~m} \times 400 \mathrm{~m}$, incorrendo a variação em alguns poucos metros de diferença entre os lotes. No entanto, a área irrigável respeita o limite estabelecido de 5 ha. referente ao consumo de água a partir dos canais de irrigação, com vistas a recuperar o capital investido no sistema de irrigação do lote. Quanto ao pagamento da parcela de terra recebida, ficou estabelecido que o valor da terra recebida pelo assentado deveria ser pago no prazo de 20 anos, com carência de cinco anos e juros de 6\% ao ano (SOARES, 1999, p. 113).

\section{Processo de seleção das Glebas D, C3, F e B}

$\mathrm{Na}$ medida que foi iniciada a operação da Etapa I, o projeto piloto Mocambinho implantado no início da década de 1980 foi incorporado a Etapa I (tratado no capítulo 2 deste trabalho), restando como o primeiro grupo de assentados do Projeto Jaíba, identificados como Gleba D. Segundo Rodrigues (1998), quando da operacionalização do Projeto Jaíba e de toda a infraestrutura de irrigação ali construída, foi a vez da gleba F, composta por 326 lotes, a receber os assentados no ano de 1989. Um ano depois, seria iniciada a seleção para a gleba C3, com 57 lotes, concluída em 1993.

Ao final de 1995, 230 lotes que compunham a gleba B, estavam com a infraestrutura pronta para assentamento, e o assentamento foi efetivado em 1996.

Mediante a dificuldade em encontrar documentos oficiais que tratassem acerca do tema, durante as entrevistas realizadas por esta pesquisa, foi perguntado aos irrigantes quais eram as condições de seleção definidas para a escolha dos ocupantes das glebas D, F, C3 e B. A mesma questão foi direcionada aos entrevistados da CODEVASF e DIJ, e mediante as respostas obtidas, foi possível identificar que os critérios estavam correlacionados as condições socioeconômicas das famílias e não à capacidade ou experiência na lida com a terra. Os critérios apontados como preponderantes pelos entrevistados foram:

a. Não portar da propriedade de algum imóvel rural

b. Residir na região Norte de Minas

c. Não possuir emprego formal (carteira assinada)

d. Famílias com maior número de dependentes

e. Ter idade entre 21 e 60 anos

f. Não ter sido beneficiado em programas de colonização ou reforma agrária 
Tais informações acerca do critério de seleção também foram confirmadas através da pesquisa de opinião, em que os responsáveis pelo Sindicato dos Trabalhadores Rurais e EMATER em suas considerações, citaram a heterogeneidade dos ocupantes da Etapa I do Projeto Jaíba nas primeiras glebas ocupadas, essencialmente composta por pintores, feirantes, pedreiros, parceiros, trabalhadores agrícolas, dentre outros.

É possível perceber que não houve qualquer preocupação referente ao fato da experiência prévia na agricultura, demonstrando o desalinhamento do processo de seleção com a proposta original do perímetro irrigado, que era de constituir o perímetro irrigado em um pólo de fruticultura em médio prazo. Os entes selecionados para compor o assentamento, dispunham de pouca ou nenhuma experiência no cultivo agrícola.

Por sua vez, o Convênio $n^{\circ} 0038 / 86$ realizado entre o Ministro Extraordinário para Assuntos de Irrigação e a Secretaria de Agricultura e Pecuária do Estado de Minas Gerais, estabeleceu que a Ruralminas seria o órgão responsável em fornecer as capacitações, apoio e assistência técnica necessária aos assentados; porém, segundo as entrevistas realizadas, de meados 1990 até 2003, este tipo de serviço foi ofertado de modo precário, restrito a resolução de questões ligadas ao solo, em que a Emater atendia aos colonos com um equipe reduzida, a mesma que atendia ao restante da comunidade rural dos municípios de Jaíba e Manga.

\section{Seleção da Gleba A}

O processo de seleção e assentamento da Gleba A foi o último a ser realizado, dada a sua localização, pois era a área mais distante da sede administrativa do perímetro irrigado, localizada na gleba $\mathrm{D}$, e por ser tratar da gleba com maior número de lotes, 845 no total.

Esta gleba teve sua infraestrutura finalizada em 1997 e no mesmo ano passou a receber os novos irrigantes, restando a sua ocupação realizada de forma parcelada, haja vista que a quantidade de lotes e famílias selecionadas.

Os critérios definidos para o processo de seleção para a gleba A foram alterados, deixando de seguir o padrão definidos para as glebas D, F, C3 e $\mathrm{B}$, dadas as dificuldades encontradas no cultivo irrigado pelos primeiros assentados (CODEVASF, mimeo).

Segundo o levantamento realizado por esta pesquisa, através um encontro entre representantes do Sindicato de Trabalhadores do município de Jaíba, Igreja Católica, Banco do Brasil, Caixa Econômica Federal, Ruralminas,
CODEVASF, Instituto Nacional de Colonização e Reforma Agrária-INCRA e EMATER, foi instituído um novo perfil de irrigante para compor o processo de seleção, com a finalidade de tornar o desenvolvimento dos irrigantes da gleba A e consequentemente da Etapa I, mais alinhada ao planejamento inicial do Projeto Jaíba: inserir os agricultores rurais assentados no mercado da fruticultura, de modo a promover a expansão da economia regional e o desenvolvimento da agroindústria (RURALMINAS, s.d.).

Assim sendo, os critérios privilegiados para compor o processo de seleção dos assentados da gleba A, foram:

a. Ser agricultor ou possuir experiência com o cultivo agrícola

b. Não portar da propriedade de imóvel rural

c. Residir na região

d. Renda inferior a dois salários mínimos em atividades não-rurais

e. Famílias menores, com até 03 dependentes

f. Não ser funcionário público, militar ou autárquico

g. Não ter sido beneficiado em programas de colonização ou reforma agrária

h. Apresentar atestados de bons antecedentes criminais

i. Ter experiência com irrigação (facultativa)

Tais critérios, segundo a CODEVASF (mimeo), estavam previstos na Lei de Irrigação e no Estatuto da Terra, porém, mediante algumas alterações ${ }^{11}$, estabeleceram um novo padrão de irrigantes para a Gleba $\mathrm{A}$, em que a condição prévia de experiência na agricultura passou a ser considerada, bem como, uma formação familiar com menor número de filhos.

\section{CONCLUSÃo da ETAPA I - FASE dE ASSENTAMENTo}

O processo de assentamento das famílias selecionadas para compor a Etapa I do Projeto Jaíba, foi marcado pela morosidade. Foram necessários aproximados dezesseis anos para a destinação de todos os lotes. Tal

${ }^{11}$ Nos últimos processos de seleção, as famílias com maior nível de escolaridade receberam pontuação maior, bem
como, famílias com menores e com conhecimento prévio no cultivo da agricultura irrigada, foram privilegiadas. 
morosidade, é justificada pela CODEVASF como necessária para adequação dos critérios de seleção ao longo do tempo, pois apenas desta forma o desenvolvimento do Projeto Jaíba poderia ser alcançado ${ }^{12}$.

Em 2006, a Etapa I do Projeto Jaíba contava com 1363 de famílias assentadas, sendo que até o final deste mesmo ano, foram assentados mais 454 famílias de colonos irrigantes, concluindo a destinação dos lotes da gleba A e, portanto, o assentamento das 1828 famílias de colonos, conforme previsto no projeto inicial para a Etapa I. Isto posto, o término do assentamento das famílias irrigantes, previsto para 1993, foi concluído apenas em 2006.

É importante destacar que dentre a área destinada a etapa I do Projeto de Irrigação, haviam lotes pertencentes as prefeituras de Jaíba e Matias Cardoso, transformados em 140 lotes de pequenos e médios empresários, e duas fazendas. Os canais construídos no entorno das empresas Agrivale (desativada atualmente) e Brasnica, estava autorizada a utilizar a infraestrutura mediante transporte das águas do canal, dado o pagamento devido da utilização (CODEVASF, s.d.). E este cenário fundiário diverso, será o tema de análise para o próximo item deste trabalho.

\section{Análise da Estrutura Fundiária do Projeto Jaíba Etapa I:}

\section{ColonizaÇão Irrigada}

De acordo com o Quadro 1, a Etapa I do Projeto Jaíba, área destinada aos pequenos agricultores, ocupa uma área total bruta de 14.362,20 ha. Contudo, descontadas as áreas comuns destinadas a infraestrutura de irrigação, a área total irrigável é de 9.346,68 ha, divididos em 1826 lotes familiares de até 05 hectares.

Em consulta ao SICOB - Sistema de Cobrança da CODEVASF, que trata do cadastro de cobrança referente a amortização e cobrança do valor K1, em novembro de 2017, os lotes destinados aos assentados na Etapa I, estavam distribuídos da seguinte Tabela 1 abaixo.

A partir da distribuição dos lotes apresentada na Tabela 01, é possível auferir que que a totalidade dos lotes disponíveis (1828 lotes), não estavam ocupados, podendo ser explicada a diferença de lotes vazios pela desistência formalizada de alguns assentados junto a CODEVASF, ou ainda, lotes que não tiveram as condições de seleção atendidas ${ }^{13}$. Através da disposição dos

\footnotetext{
${ }^{2}$ Vide entrevistas realizadas em Setembro de 2017

${ }^{3}$ Conforme posicionamento formal da CODEVASF, após envio de questionamento por email.
}

Tabela 01 - Irrigantes assentados conforme Sistema de Cobrança da CODEVASF - SICOB - Projeto Jaíba Etapa I.

\begin{tabular}{|c|c|c|}
\hline \multicolumn{3}{|c|}{ Assentados/Estrutura Fundiária * } \\
\hline $\begin{array}{l}\text { Condição do Assentado: } \\
\text { dos nesta condição }\end{array}$ & Qtde de Assenta- & Qtde de Lotes \\
\hline Portador de 01 lote & 1662 & 1662 \\
\hline Portador de 02 lotes & 29 & 58 \\
\hline Portador de 03 lotes & 15 & 45 \\
\hline Portador de 04 lotes & 1 & 4 \\
\hline Totais*: & 1707 & 1769 \\
\hline
\end{tabular}

dados é possível identificar que aproximadamente 90,92\% das famílias não tiveram as condições de seleção atendidas ${ }^{14}$. Através da disposição dos dados é possível identificar que aproximadamente $90,92 \%$ das famílias assentadas foram contempladas com 1 lote de até 5 hectares, ou seja, a maior parcela dos selecionados não dispunha de capacidade financeira para se comprometer para com a aquisição de mais de 01 lote, conforme as regras do processo de seleção.

Contudo, a estrutura fundiária da Etapa I do Projeto Jaíba, em especial da área destinada a colonização/assentamento dos irrigantes, pode ser considerada como uma contradição no período atual, pois os dados SICOB, disponibilizados pela CODEVASF, não retratam a estrutura fundiária observada, pois durante o período de pesquisa de campo, foi recorrente a identificação pela pesquisadora, de cercas que contornavam áreas superiores a 5 ou 10 hectares de terra irrigada.

Durante a pesquisa de campo, muitas dificuldades foram encontradas, dentre elas, entrevistar aqueles que saíram, apenas, uma entrevista/ observação foi alcançada, pois geralmente voltam para a cidade de origem (a maioria do Norte de Minas Gerais) ou vão para as cidades maiores da região em busca de melhores oportunidades; ampliar o número de observações, pois alguns entrevistados não disponibilizaram as informações pessoais ou sobre o processo de compra, qual a motivação principal da aquisição, dentre outros, apenas disseram que possuíam lotes no perímetro e quantidade; acessar

\footnotetext{
${ }^{14}$ Conforme posicionamento formal da CODEVASF, após envio de questionamento por email.
} 
aos lotes que estão localizados nas extremidades dos perímetros, pois as estradas são de terra e em péssimas condições de tráfego em carro comum. De todo modo, todos aqueles agricultores que tivemos a oportunidade de entrevistar, nem que fosse de modo muito informal dada a desconfiança de muitos, informaram que é crescente a compra de lotes por uma mesma pessoa e que a prática é considerada como normal, pois, na medida que a atividade dá certo, compra-se mais lotes quando a oportunidade aparece.

Dadas tais condições e a metodologia de pesquisa definida, as entrevistas foram feitas mediante a definição de unidade de negócio, ou ainda, quantidade de lotes para o mesmo irrigante, formalizado por meio da Concessão de Direito Real de Uso - CDRU e Contrato de Compra e Venda, também chamado de Contrato de Gaveta, por não dispor de registro oficial no cartório de títulos.

Portanto, foram entrevistados 21 agricultores na Etapa I, que possibilitaram mediante a análise do domínio originário o alcance de 120 lotes de até 05 hectares, 6,56\% dos 1826 lotes que compõem a Etapa I e 6,78\% dos 1769 considerados como ocupados pela CODEVASF em novembro de 2017.

A distribuição das observações dentre as glebas foi ordenada mediante o quadro 03:

Quadro 03 - Distribuição por Gleba dos Lotes Analisados - Projeto Jaíba Etapa I.

\begin{tabular}{|l|l|l|l|}
\hline $\begin{array}{l}\text { Observaçoes - Lo- } \\
\text { tes por Gleba: }\end{array}$ & $\begin{array}{l}\text { Quantidade Total de } \\
\text { lotes }\end{array}$ & $\begin{array}{l}\text { Quantidade de lotes } \\
\text { observados durante } \\
\text { a pesquisa }\end{array}$ & $\begin{array}{l}(\%) \\
\text { Percentual }\end{array}$ \\
\hline Gleba A & 845 & 67 & 7,92 \\
\hline Gleba B & 399 & 23 & 5,76 \\
\hline Gleba C & 57 & 3 & 5,26 \\
\hline Gleba D & 199 & 4 & $2,01^{2}$ \\
\hline Gleba F & 326 & 23 & 7,05 \\
\hline Total: & 1826 & 120 & \\
\hline
\end{tabular}

Fonte: Pesquisa de Campo

A condição de formalidade dos 120 lotes analisados foi um fator que chamou a atenção durante o processo de leitura dos dados e apresentou distribuição conforme expresso no Quadro 04:
Quadro 04 - Condição Formalidade dos Lotes Analisados - Projeto Jaíba Etapa I

\begin{tabular}{|l|c|}
\hline \multicolumn{2}{|c|}{ Condição de Formalidade } \\
\hline Condição de Formalidade dos Lotes & Qtde \\
\hline Pequeno Irrigante - CDRU - Concessão de Direito Real de Uso & 9 \\
\hline Contrato de Compra e Venda com Registro no Cartório de Notas & 110 \\
\hline Contrato de Compra e Venda sem Registro - gaveta & 1 \\
\hline Pequeno Irrigante Portador de Matrícula do Imóvel & 0 \\
\hline Total: & 120 \\
\hline
\end{tabular}

Fonte: Pesquisa de Campo

É possível perceber através do quadro 04, que a condição de formalidade dos lotes analisados é temerária, sendo que apenas nove lotes pertencem a irrigantes assentados, detentores da Concessão de Direito Real de Uso - CDRU expedido pela Ruralminas, logo, ainda não cumpriram com a totalidade do pagamento dos valores referente ao K1, K2 e amortização do lote. Os lotes em condição de Contrato de Compra e Venda com Registro no Cartório de Notas, foram de 110 no total, representando mais de 91,6\% da amostra, ratificando a condição de normalidade da prática de compra e venda dos lotes agrícolas na Etapa I, mesmo que diante da irregularidade do ato. Isto posto, é possível concluir que nenhuma das observações dispunham de Registro no Cartório de Títulos. Em tese, ninguém é dono do lote ou dos lotes que ocupam, possuem apenas a posse.

A questão da formalidade da posse dos lotes da Etapa I, é um imbróglio que se desenvolveu desde a primeira fase do assentamento, ainda na década de 1980. Devido a diversas motivações, como endividamento, falta de aptidão, desinteresse, entre outros, assentados não permaneceram nos lotes que receberam, negociando no mercado informal o direito à terra que receberam. Tais negociações muitas vezes foram feitas sob o chamado contrato de gaveta com registro em cartório de notas, trocas em veículos, casas na cidade ou até mesmo em áreas de sequeiro (vide discurso registrado nas entrevistas coletadas).

O que de fato percebe-se ao visitar o perímetro irrigado, é que existe ali uma realidade bem diferente daquela apresentada pela CODEVASF em relatórios oficiais. A presença de produtores agrícolas que não foram selecionados por meio do processo de assentamento nos lotes da Etapa I é uma 
prática considerada como comum no perímetro irrigado; a compra de um lote localizado no assentamento, em tempos atuais, é vista como uma questão de oportunidade de negócio, contrariando a premissa inicial e a condição legal que privilegiava o assentamento de famílias que não tinham acesso à terra.

Um outro fator identificado durante a visita no perímetro irrigado, foi a questão do arrendamento da terra. Apesar de pouco comum, nos questionários propusemos a seguinte questão: “O Sr. (a) arrendaria o seu lote?", e muitos responderam positivamente, inclusive dois entrevistados, pequenos irrigantes selecionados pela CODEVASF, ambos usufruem da aposentadoria rural e compartilharam que arrendam o lote que possuem na atualidade, pois não detém mais da força necessária para realizar o plantio e seus filhos não quiseram permanecer cultivando a terra. Logo, o arrendamento lhes serve como uma maneira de complementar a renda de forma segura por um determinado período de tempo. Portanto, em análise primária acerca do perímetro irrigado, que teve seus primeiros assentados em 1989 e a idade destes primeiros assentados, compreende-se que muitos destes já estão em fase de aposentadoria, dado que mais de trinta anos se passaram, podendo muitos casos similares, se repetirem no perímetro irrigado.

A distribuição dos lotes analisados durante a fase de pesquisa alcançou uma representatividade considerável quanto ao número de observações necessárias para análise da estrutura fundiária da Etapa I, dada as dificuldades encontradas, bem como, os limites da pesquisa (acesso aos lotes localizados nas extremidades do perímetro irrigado, entrevistas aos colonos, financiamento da pesquisa, dentre outros). Dos 120 lotes aos quais obtivemos acesso, todos como anteriormente dito, eram provenientes da Concessão de Direito Real de Uso - CDRU, vinculados a 120 colonos irrigantes diferentes, logo, o número de observações espelhou uma distribuição fundiária inicial, de 1 lote de 05 hectares para 1 irrigante perante a condição formal e legal de quando as famílias foram assentadas.

Assim sendo, foram alcançados os indícios necessários para que a hipótese de concentração fundiária em um assentamento, pudesse ser validada, conforme o quadro 05 .

Considerando o limite estabelecido pela CODEVASF e RURALMINAS de lotes a serem ocupados por cada colono assentado (4 lotes), é possível compreender através do quadro 05, que dos 21 entrevistados, 14 foram classificados como produtores agrícolas, pois acessaram as terras via a negociação informal dos lotes. Destes 14 produtores agrícolas, 10
Quadro 05 ${ }^{15}$ - Caracterização e Distribuição da Posse dos Lotes Analisados - Projeto Jaíba Etapa I.

\begin{tabular}{|c|c|c|c|}
\hline Entrevistados & $\begin{array}{l}\text { Condição do Domínio do } \\
\text { Lote }\end{array}$ & $\begin{array}{l}\text { Quantidade de Lo- } \\
\text { tes que possui na } \\
\text { Etapa I }\end{array}$ & $\begin{array}{ll}\begin{array}{l}\text { Área } \\
\text { (ha) }\end{array} & \text { Total } \\
\end{array}$ \\
\hline 1 & Produtor Agrícola & 07 lotes & 35 \\
\hline 2 & Colono Irrigante & 03 lotes* & 15 \\
\hline 3 & Produtor Agrícola & 05 lotes & 25 \\
\hline 4 & Produtor Agrícola & 04 lotes & 20 \\
\hline 5 & Produtor Agrícola & 08 lotes & 40 \\
\hline 6 & Colono Irrigante & 03 lotes & 15 \\
\hline 7 & Produtor Agrícola & 03 lotes & 15 \\
\hline 8 & Produtor Agrícola & 07 lotes & 35 \\
\hline 9 & Produtor Agrícola & 02 lotes & 10 \\
\hline 10 & Produtor Agrícola & 01 lote & 5 \\
\hline 11 & Colono Irrigante & 01 lote & 5 \\
\hline 12 & Colono Irrigante & 01 lote & 5 \\
\hline 13 & Colono Irrigante & 01 lote & 5 \\
\hline 14 & Colono Irrigante & 01 lote & 5 \\
\hline 15 & Produtor Agrícola & $\underline{05 \text { lotes }}$ & 25 \\
\hline 16 & Colono Irrigante & 03 lotes & 15 \\
\hline 17 & Produtor Agrícola & 20 lotes & $\underline{100}$ \\
\hline 18 & Produtor Agrícola & 12 lotes & $\underline{60}$ \\
\hline 19 & Produtor Agrícola & 15 lotes & $\underline{75}$ \\
\hline 20 & Produtor Agrícola & 10 lotes & $\underline{50}$ \\
\hline 21 & Produtor Agrícola & 08 lotes & 40 \\
\hline
\end{tabular}

Fonte: Pesquisa de Campo.

excedem o limite máximo da posse de lotes por indivíduos, contrariando o objetivo inicial do perímetro irrigado para a Etapa I, que era promover uma distribuição mais igualitária dentre os colonos. Os quatro restantes, apenas 1 produtor agrícola detém de 1 lote, os demais possuem ao menos 02 lotes em sua posse.

${ }^{15}$ Legenda para o quadro: Foi considerado como produtor agrícola aquele que acessou a terra por meio da aquisição informal do lote, podendo ser também considerado como o new settler ou new colonist. $\mathrm{O}$ termo colono irrigante tratou de caracterizar o irrigante selecionado através da Ruralminas para ocupar a Etapa I. *O entrevistado acessou 1 lote através do processo de seleção realizado pela Ruralminas e com o passar do tempo adquiriu mais 2 lotes, através da negociação informal com outros assentados. 
Ainda com base no quadro 05 , quando analisada a distribuição da posse dos 7 entrevistados que se identificaram como colonos irrigantes, 4 afirmaram possuir 1 lote. Dois colonos apresentaram mais de 1 lote em sua posse, mediante a informação de que os lotes adicionais foram adquiridos via negociação informal com outros colonos que desistiram do cultivo na Etapa I e venderam seus lotes. Apenas 1 colono irrigante possui 03 lotes agrícolas, todos mediante Concessão de Direito Real de Uso - CDRU. Logo, quando da formulação do problema de pesquisa, os pressupostos sugeridos de fato retratam parte da formatação da estrutura fundiária da Etapa I assumida ao longo dos anos, de modo que alguns colonos, efetivamente adquiriram áreas de vizinhos que desistiram do cultivo, e esta aquisição tornou-se possível, conforme ratificação através dos questionários, através do sucesso no cultivo da fruticultura irrigada.

Quando organizados os dados apresentados no quadro 05 através do método de estratificação de área (ha), é possível visualizar de maneira mais sucinta o modo como se encontra distribuída a posse da terra entre os entrevistados, vide quadro 06 :

Quadro 06 - Percentuais do Número de Estabelecimentos segundo os estratos de área (ha) em relação aos totais. Projeto Jaíba Etapa I.

\begin{tabular}{|c|c|c|}
\hline Estratos* $^{*}$ & Número & \% \\
\hline $0-10$ & 6 & 28,57 \\
\hline $10-20$ & 5 & 23,81 \\
\hline $20-50$ & 7 & 33,33 \\
\hline $50-100$ & 3 & 14,29 \\
\hline $100+$ & - & - \\
\hline Total & $\mathbf{2 1}$ & $\mathbf{1 0 0}$ \\
\hline
\end{tabular}

Fonte: Pesquisa de Campo

*Distribuição com Base na Metodologia Utilizada pelo Censo AgropecuárioIBGE.

Quando observado o quadro acima, percebe-se que a maior parte dos estabelecimentos, $33,33 \%$ agrupam-se no estrato que varia de 20 a 50 ha, e a participação de $14,29 \%$ dos estabelecimentos no estrato 50 a 100 ha merece atenção. A soma destes dois estratos em termos de área representa 47,62\% do total da pesquisa, demonstrando a mudança no padrão da composição fundiária dentro da área destinada ao assentamento, uma vez que o limite de lotes em posse de um mesmo indivíduo e/ou cadastro de pessoa física-cpf deveria ser de no máximo 20 hectares; logo a totalidade da distribuição que atende a esta regulamentação, deveria situar-se entre os estratos 0 a 10 e 10 a 20 hectares, o que não ocorre na amostra coletada, apesar de representarem a maioria $-52,38 \%$ dos estabelecimentos.

Por meio da distribuição da posse dos lotes retratada, é possível afirmar que tem ocorrido um processo de concentração da posse da terra na Etapa I do Projeto Jaíba, ainda que se consideradas as restrições do número de observações alcançados por meio da pesquisa de campo. Aqueles denominados como produtores agrícolas possuem área que variam entre 07 lotes - 35 hectares, chegando até o caso mais abrangente de 20 lotes - 100 hectares, em posse de um único agricultor, fato que segundo entrevistados não é isolado.

Em busca de demonstrar de forma mais clara o peso da distribuição fundiária observada, apresenta-se na sequência, o cálculo do índice de Gini - que tem a finalidade de medir a desigualdade da posse da terra para o presente estudo.

Analisada a totalidade da amostra (120 lotes agrícolas observados), o nível calculado para o Índice de Gini das observações, ficou em torno de 0,493, que de acordo com Câmara (1949), é classificada como uma concentração média da posse da terra, com valores próximos a aquele identificado para o semiárido mineiro, 0,536 conforme Censo Agropecuário $(2006)^{16}$. Se comparado com a estrutura fundiária brasileira, que entre 1967 e 2000, apresentou concentração fundiária em torno de 0,80 , o valor de 0,493 , pode ser considerado como baixo. Entretanto, estamos tratando do nível de concentração da posse da terra em uma área que foi destinada a famílias agricultoras, por meio de uma ação de colonização específica para o perímetro irrigado, que em sua concepção previa a garantia do acesso à terra e aos meios de produção (irrigação), em que o acúmulo de parcelas superiores a 20 hectares não é permitido do ponto de vista legal e regulamentar do assentamento.

E tais resultados são explicados com base nos processos de compra e venda informal dos lotes (vide entrevistas), onde foi possível perceber que esta atividade se iniciou na década de 1990, intensificou nos anos 2000 e ainda ocorre em um ritmo compassado na atualidade, em que a compra de um lote adicional é vista como uma oportunidade de ampliar a produção ${ }^{16}$ Logo, os movimentos de transformação da estrutura fundiária do assentamento podem refletir as mesmas
condições do cenário regional, o que carece de estudo específico. 
em meio a um ambiente de expansão da fruticultura irrigada.

De todo modo, por intermédio das entrevistas de opinião realizadas com os seis representantes da CODEVASF, IMA, EMATER, DIJ, Associação de Produtores da Gleba A e Prefeitura Municipal de Jaíba, a hipótese de concentração também foi corroborada por todos os entrevistados, e assumiu as mesmas condições verificadas nas entrevistas dos agricultores, de que este processo não tem sido realizado a toque de caixa, mas sim, ao longo do tempo, na medida em que o perímetro irrigado tem se consolidado.

\section{Conclusão}

Esta pesquisa em sua fase final poderia presumir que o processo de colonização realizado no perímetro irrigável Projeto Jaíba Etapa I agiu em atendimento a necessidade de assentamento de agricultores com o objetivo de promover a democratização do acesso à terra, bem como, para o desenvolvimento da sociedade local e regional. Contudo, tal condição prevista pelos órgãos responsáveis pelo programa de assentamento não vigorou, pois compreendeu-se, que de fato, o acesso à terra e à irrigação não foram suficientes para o êxito da Etapa I do Projeto Jaíba, visto que condições como: processo de seleção mediante o perfil necessário para o cultivo irrigado, assistência técnica suficiente desde a fase inicial do assentamento, acesso ao crédito, e condições mínimas para moradia, educação e saúde, não poderiam estar ausentes.

Segundo Greenhalgh (1996, p. 4), há uma resistência em efetivar a reforma agrária no Brasil, de modo que para muitos grupos políticos e sociais, a reforma agrária pode ter perdido o sentido, mas continua como uma necessidade entre os trabalhadores rurais e até mesmo a população urbana, originária do rural, que enseja o retorno ou a conquista de sua parcela de terra. E esta necessidade, se coloca como uma alternativa para o desenvolvimento socioeconômico nacional. Mas também é sabido, que a reforma agrária não pode ser empreendida apenas através de uma mera distribuição de lotes como se observa em muitos assentamentos do território nacional e para o caso apresentado neste estudo. É preciso que ocorra uma mudança radical na estrutura política e social do campo, para que o assentado venha ser dotado de maior autonomia (para o caso do Projeto Jaíba, o cultivo foi direcionado e a CODEVASF e RURALMINAS fixaram incentivos e estrutura de irrigação próprias a fruticultura, reduzindo o poder de barganha de muitos assentados em cultivar e comercializar o fruto ao qual dispunha de aptidão e/ou interesse).

De acordo com Silveira:

(...) a reforma agrária é entendida como uma política social a fim de atingir a redução da desigualdade no meio rural. Isso significa dizer que ela envolve não só a distribuição racional de terra, mas também a modificação das relações de trabalho e do relacionamento do homem no meio. Enfim, pressupõe mudanças no meio rural de forma a oferecer condições de uma vida digna no campo (SILVEIRA, 2003, p.97).

Logo, o propósito final de uma política que promove a distribuição da terra e o acesso a água em meio ao semiárido deveria ser a fixação do homem no campo. E como instrumentos para efetivar a desejada permanência, infraestruturas básicas como serviços públicos (saúde, educação e assistência técnica suficiente), acesso ao crédito e estradas rurais se fazem necessários, caso contrário, torna-se o intento da atividade rural pelo assentado, penosa e infrutífera, dispensado os casos em que os selecionados dispuserem de capital social e monetário suficiente para instaurar o cultivo.

Trazida tal análise para o caso observado neste estudo, a hipótese inicial desta pesquisa de que permaneceram em seus lotes aqueles assentados que obtiveram sucesso no cultivo irrigado e que mediante a desistência de assentados vizinhos adquiriram lotes adicionais em um mercado informal, pode ser confirmada. Mas também revelam que em grande maioria, as negociações dos lotes foram realizadas entre colonos e produtores agrícolas provenientes das áreas de sequeiro da região, motivados pelo aumento da oferta da terra irrigada, negociadas a um preço abaixo do mercado, confirmando o entendimento acerca do funcionamento dos mercados de terras conforme Reydon (1992), que aponta que tais mercados são considerados imperfeitos ou informais devido as desigualdades expressivas na distribuição da propriedade da terra, ações individuais dos agentes econômicos locais, uma vez que a terra não é um produto homogêneo (possui variações em sua extensão, bem como, na qualidade dos solos), condições espaciais, ou ainda, geográficas capazes de alterar o preço e agentes econômicos sem-terra que a procuram, porém, não possuem condições econômicas de sustentar a sua demanda.

Na medida que entes externos adquirirem lotes em uma área direcionada a agricultura familiar, a parcela que permanece assentada, assistiu à 
substituição de seus pares por indivíduos especializados no cultivo da fruticultura ou de indivíduos que dispõem do capital financeiro necessário para empreender este cultivo, demonstrando a dualidade entre irrigantes assentados e produtores agrícolas (novo colono/assentado) na área destinada aos selecionados. Esta dualidade por sua vez, revela a ingerência do Estado em não efetivar a devida fiscalização da posse dos lotes do assentamento, bem como, a ingerência do Estado em executar uma política que não coaduna e não propicia o desenvolvimento do assentado.

De todo modo, as mudanças na composição fundiária do assentamento Etapa I Projeto Jaíba, podem ser vistas como resultados de um conjunto de ações que não primaram pela sustentação dos assentados na área recebida, pois, desde a concepção inicial do perímetro irrigado, não fazia parte do interesse maior do Estado dinamizar a concentração da posse da terra na região, mas sim, transformar o perímetro irrigado em uma esfera de desenvolvimento agrícola capaz de integrar semiárido mineiro mais integrado ao restante da economia estadual. $\mathrm{O}$ que de fato se observou, foi uma distribuição de lotes a famílias previamente selecionadas, em cumprimento a uma necessidade de financiamento (Banco Mundial) para o funcionamento do perímetro irrigável. E esta seleção cumpriu seu papel: direcionar lotes a famílias que não dispunham do acesso à terra, contudo, não foi capaz de prever ou subsidiar as condições que promoveriam a permanência dos selecionados nos lotes recebidos.

A pesquisa de campo foi primordial para conferir evidências de que este movimento de concentração da posse da terra não tem acontecido de modo aleatório, mas que é delineado ao longo de um processo falho de assentamento das famílias selecionadas (pautado em um perfil de assentados que não atendiam aos requisitos necessários para o cultivo irrigado), ingerência da infraestrutura necessária para permanência dos assentados (assistência técnica, escolas, postos de saúde, mobilidade, dentre outros) e primordialmente, a definição prévia do cultivo a ser empreendido pelos colonos, a fruticultura, fato que submeteu os assentados a uma situação análoga a uma camisa de força, pois grande parte não detinha de conhecimentos na lida da terra, e aqueles que dispunham da experiência para com o cultivo agrícola, estavam pautados pela lógica do cultivo de sequeiro, amplamente exercida no semiárido nacional.

E diante das dificuldades enfrentadas pelos irrigantes selecionados, a presença dos produtores agrícolas, tornar-se-ia como "comum" dentre o assentamento, em um movimento de negociação informal de lotes (compra e venda) a um baixo custo, permeada pela informalidade e orientada para a concentração da posse da terra em uma área de colonização, que passou a contar com a soma de um lote por produtor agrícola, a cada assentado desistente da atividade rural.

\section{REFERÊNCIAS}

BRASIL, Decreto-Lei n⿳亠口冋106 de 17 de junho de 1970. Cria o Programa de Integração Nacional, altera a legislação do imposto de renda das pessoas jurídicas na parte referente a incentivos fiscais e dá outras providências. Diário Oficial da União, Brasília, DF, 17 jun. 1970. Disponível em: http:// www.planalto.gov.br/ccivil 03/decreto-lei/1965-1988/Del1106.htm. Acesso em 18 de abril de 2017.

BRASIL, Decreto $\mathbf{n}^{\mathbf{0} 59.428,} 01$ de novembro de 1966. Regulamenta os Capítulos I e II do Título II, o Capítulo II do Título III, e os arts. 81 - 82 - 83 - 91 - 109 - 111 - 114 - 115 e 126 da Lei no 4.504 , de 30 de novembro de 1964, o art. 22 do Decreto-lei $\mathrm{n}^{\circ} 22.239$, de 19 de dezembro de 1932, e os arts. 9 - 10 - $11-12$ - 22 e 23 da Lei $n^{\circ} 4.947$, de 6 de abril de 1966 - Colonização e outras formas de acessa à propriedade. Diário Oficial da União, Brasília, DF, 01 nov. 1966. Disponível em: http://www.planalto.gov. br/ccivil_03/decreto/antigos/d59428.htm. Acesso em: 01/07/2017.

BRASIL, Decreto $\mathbf{n}^{\mathbf{0} 74.794,} 31$ de outubro de 1974. Dispõe sobre a criação do Programa de Desenvolvimento de Áreas Integradas do Nordeste (POLONORDESTE). Diário Oficial da União, Brasília, DF, 31 out. 1974. Seção 1, Página 12391. Disponível em: http://www2.camara.leg. br/legin/fed/decret/1970-1979/decreto-74794-30-outubro-1974-423254publicacaooriginal-1-pe.html. Acesso em 18/04/2017.

BRASIL. A irrigação no Brasil: Situação e Diretrizes. Brasília, 2008. Disponível em: http://www.integracao.gov.br/documents/10157/3672008/ A+irrigacao+no+Brasil+-+diretrizes.pdf/b88c 745b-f5b3-4f3d-b375483033a2e80c. Acesso em 27 de março de 2017.

BRASIL. IBGE Censo Agropecuário de 2006. Disponível em: https:// biblioteca.ibge.gov.br/visualizacao/periodicos/51/agro_2006.pdf. Acesso 
em: 18/07/2017.

BRASIL. IBGE Censo Demográfico de 2010. Disponível em: https:// censo2010.ibge.gov.br/resultados.html.. Acesso em: 18/07/2017.

BRITO, M. S. O Programa Nacional de Irrigação: uma avaliação prévia dos resultados. Revista Brasileira de Geografia. Rio de Janeiro, v. 53, n. 2. p. 113-125, abr./jun. 1991.

CÂMARA, L. A concentração da propriedade agrária no Brasil. Boletim Geográfico, Rio de Janeiro, V.7, nº .77 , p. 37 - 58, 1949.

CARVALHO, J. O. O nordeste semiárido: questões de economia política e de política econômica. Tese de Doutoramento. Campinas: Instituto de Economia - Unicamp, 1985.

CODEVASF - Companhia de Desenvolvimento dos Vales do São Francisco e Alto Parnaíba. Relatório Anual de 1983. Brasília, 1984, 110 p.

CODEVASF - Companhia de Desenvolvimento dos Vales do São Francisco e Alto Parnaíba. História do Projeto Jaíba. MIMEO.

CODEVASF - COMPANHIA DE DESENVOLVIMENTO DO VALE DO SÃO FRANCISCO. RURALMINAS. Distrito de Irrigação. Perímetro irrigado de Jaíba. Jaíba, s.d. (Manual informativo).

COUTO, D. Análise do Cenário Agrícola para Delineamento do Serviço de Assistência Técnica e Extensão Rural - Caso Perímetro Irrigado Jaíba, Sistema 5, 6, 7 e 8. 2016. Trabalho de Conclusão de Curso - Extensão Ambiental para o Desenvolvimento Sustentável. UFLA. Lavras.

DEININGER, K.; BYERLEE, D.The Rise of Large-Scale Farms in LandAbundant Developing Countries: Does it have a future? Disponível em: http://cega.berkeley.edu/assets/cega events/30/AfDR_Deininger-Byerlee_Large-Farm-Small-Farm-Debate_P-S.pdf. Acesso em 20/04/2017.

DEAN, W. "Latifundia and land policy in nineteenth century Brazil". Hispanic American Historical Review, v.51, nº 4, 1971.
PESSOA, D. A estrutura fundiária e a diferenciação social. Políticas Fundiária no Nordeste: caminhos e descaminhos. Coor. Dirceu Pessoa. Fundação Joaquim Nabuco. Editora Massangana. Recife, Brasil, 1990.

PLANVASF. Plano Diretor para o Desenvolvimento do Vale do São Francisco. Programa para o Desenvolvimento da Irrigação (1989-2000). Brasília, junho de 1989. Cooperação Técnica: CODEVASF/SUDENE/ OEA. Disponível em :https://www.bdpa.cnptia.embrapa.br/consulta/ $\mathrm{sca} ? \mathrm{~b}=\mathrm{ad} \& \mathrm{id}=556264 \&$ biblioteca $=$ vazio\&busca $=$ autoria: $\% 22 \mathrm{PLANO} \% 20$ DIRETOR \% 20PARA \%200\%20DESENVOLVIMENTO \%20 DO $\% 20$ VALE $\% 20$ DO $\% 20$ SAO $\% 20$ FRANCISCO. $\% 22 \& q$ Facets $=-$ autoria:\%22 PLANO \% 20 DIRET OR \% 20 PAR A \% $200 \% 20$ DESENVOLVIMENTO $\% 20$ DO $\% 20$ VALE $\% 20$ DO $\% 20$ SAO $\% 20$ FRANCISCO. $\% 22 \&$ sort $=\&$ paginacao $=$ t\&paginaAtual $=1$. Acesso em: 01/07/2017.

POLANYI, K. A grande transformação: as origens de nossa época. Rio de Janeiro: Campus, 1980.

REYDON, B.; PLATA, L. A ampliação do acesso à terra e o Imposto Territorial Rural. XXII Encontro da ANPEC, 1995.

REYDON. B. P. Mercado de Terras Agrícolas e Determinantes de seus Preços no Brasil: Um Estudo de Caso. 1992. Unicamp, Campinas, 1992.

REYDON, B. P. e CORNELIO, F.N.M. Mercados de Terras no Brasil: estrutura e dinâmica. Brasília: Ministério do Desenvolvimento Agrário (MDA) NEAD, 2006. 444 p. (Nead Debate n.7).

REYDON, B. P. FELÍCIO, A. S. G. Fundamentos da Governança Fundiária In: FAO. Governança da Terras: da teoria à realidade brasileira. Brasília, 2017. Volume 1, capítulo 1.

RODRIGUES, L. Investimento agrícola e o grande projeto Jaíba: uma interpretação: 1970-1996. Tese de Doutorado. 337 pp. FFLCH/USP, São Paulo, 1998

RODRIGUES, L., Cardoso, J. M. A., \& Botelho, T. R. Formação social e 
econômica do norte de Minas. Montes Claros-MG. Unimontes, Montes Claros, 2000.

SILVEIRA, U. Reforma agrária: a esperança dos "sem-terra". Franca: Ed. UNESP, 2003.

SOARES, C. C. O caráter social e as perspectivas de adaptação da pequena produção inserida em projetos de concepção técnica: o caso do Projeto Jaíba. 1999. Dissertação de Mestrado. UFLA, Lavras, 1999.

VELOSO et al. Determinação do Albedo de superfície em áreas irrigadas no Projeto Jaíba (Minas Gerais) mediante imagens landsat 5 - TM. Revista Ra'ega, v. 35, p. 126-146, Dez/2015.

WANDERLEY, M. N.B. A valorização da agricultura familiar e a reivindicação da ruralidade no Brasil. In: $\mathbf{X}$ World Congressof Rural Sociology e XXXVIII Congresso Brasileiro de Economia e Sociologia Rural. Rio de Janeiro, Brasil, 2000.

\section{RÁDIO COMUNITÁRIA COMO FERRAMENTA DE AMPLIAÇÃO DA CIDADANIA: DESAFIOS, DIFICULDADES E O PAPEL DAS LIDERANÇAS}

Matheus Henrique de Souza Santos ${ }^{l}$ Ana Cláudia Fernandes Terence ${ }^{2}$

ReSUmo : Este artigo objetiva pontuar os desafios, as dificuldades e o papel de suas lideranças no processo de elaboração do projeto de implantação da rádio comunitária Monte Alegre. Para tanto se alicerça em dois aportes teóricos: a comunicação comunitária como instrumento alternativo ao sistema vigente; e a comunicação comunitária como instrumento de transformação e fortalecimento da cidadania. A rádio comunitária, um contraponto no sistema de comunicação, é uma maneira de democratizar o serviço de radiodifusão por meio da organização comunitária, porém a sua instalação demanda envolvimento e protagonismo da comunidade. Realizou-se um estudo qualitativo e exploratório, caracterizado como estudo de caso que abrangeu a reestruturação da Associação dos Moradores do Assentamento Monte Alegre na busca ao cumprimento dos requisitos para implantação da rádio, processo que contou com a vontade emergente dos seus membros empenhados em contribuir, a partir de suas perspectivas, para uma sociedade mais justa e igualitária. Houve o envolvimento de um grupo de pessoas conscientes de suas ações e desafios impostos para que a rádio se tornasse sustentável e tivesse condições de concretizar sua principal função: a cidadania ativa que possibilita aos assentados compreender que mudanças de sua realidade dependem de auto-organização. Destaca-se neste processo uma experiência de construção coletiva que resultou em avanços na organização da comunidade, com base na concepção de cidadania ativa e no protagonismo dos seus integrantes.

Administrador Público, Mestre em Ciências Sociais- Faculdade de Ciências e Letras, UNESP/Araraquara Doutorando no Programa de Política Científica e Tecnológica da Universidade de Campinas - UNICAMP/ Bolsista CAPES; mhsouzasantos@gmail.com

${ }^{2}$ Administradora Pública; Mestre e Doutora em Engenharia de Produção - USP/SP; Professora Assistente Doutor no Departamento de Administração Pública da Faculdade de Ciências e Letras, Campus Araraquara; anaterence@fclar.unesp.br 